Britton et al. (in press) International Journal of Osteoarchaeology

\title{
Isotopes and new norms: investigating the emergence of early modern UK breastfeeding practices at St. Nicholas Kirk, Aberdeen
}

Britton, Kate ${ }^{1,2^{*}}$ ( k.britton@abdn.ac.uk), McManus-Fry, Ellen ${ }^{1}$ (e.mcmanus-

fry@,reading.ac.uk), Cameron, Alison ${ }^{3}$ (cameronarch@ btinternet.com), Duffy, Paul ${ }^{4}$

(discoverbutearchaeology@gmail.com), Edouard Masson-Maclean ${ }^{1}$ (e.masson-

maclean@abdn.ac.uk), Orsolya Czére ${ }^{1}$ (‥czere@abdn.ac.uk), Nicola Smith ${ }^{1}$

(nicola.smith.13@aberdeen.ac.uk), Judith Stones ${ }^{5}$ (judith.stones@,btinternet.com), Winfield,

$\operatorname{Arthur}^{6}$ (arthurjwinfield@yahoo.com) and Gundula Müldner ${ }^{7}$ (g.h.mueldner@,reading.ac.uk)

${ }^{1}$ Department of Archaeology, University of Aberdeen, St. Mary's Building, Elphinstone

Road, Aberdeen, AB24 3UF, UK

${ }^{2}$ Department of Human Evolution, Max Planck Institute for Evolutionary Anthropology,

Deutscher Platz 6, 04103, Leipzig, Germany

${ }^{3}$ Cameron Archaeology, Aberdeen, UK

${ }^{4}$ Brandanii Archaeology and Heritage, Isle of Bute, UK

${ }^{5}$ Aberdeen Art Gallery \& Museums, Aberdeen, UK

${ }^{6}$ Project Leader, Mither Kirk Project, OpenSpace Trust, Kirk of St Nicholas Uniting, Aberdeen, UK

${ }^{7}$ Department of Archaeology, University of Reading, UK

*Corresponding author

Department of Archaeology, University of Aberdeen, St. Mary's Building, Elphinstone Road, Aberdeen, AB24 3UF, UK

Tel: $+44(0) 1224273823$

Fax: $+44(0) 1224272331$

Keywords: weaning; medieval; post-medieval; urbanism; diet; stable isotopes; bone collagen Running title: Breastfeeding practices in Medieval \& early modern Aberdeen, Scotland 


\begin{abstract}
In this study, we aim to extend the chronological, geographical and societal scope of previous bioarchaeological research on infant diet and age-at-weaning in Britain in the past through the analysis of the large Medieval and post-Medieval skeletal assemblage from St. Nicholas Kirk, Aberdeen, Scotland. Stable carbon and nitrogen isotope data were obtained from rib collagen from 67 sub-adults across the two phases, and were compared to mean adult female dietary isotope values. Nitrogen isotope data were modelled using the R Package WARN, along with previously published datasets, to provide quantitative age estimates for the commencement and completion of weaning at St. Nicholas Kirk and other Medieval and post-Medieval sites. Data from Phase A (12th-15th century AD) suggest that breastfeeding may have continued up to and beyond the age of 2 years, likely in combination with other foods. This complements previously published data from urban and rural Medieval contexts in England, highlighting similarities in infant feeding practices across very different contemporary populations. Data from postMedieval Phase B at St. Nicholas Kirk (15th-18th century AD) give new insights into early modern period breastfeeding and weaning practices, indicating that weaning commenced soon after birth and was completed relatively early (within a year). These data bridge the gap between previously published studies on Medieval and late $18^{\text {th }} / 19^{\text {th }}$ century populations from the British Isles, and suggest trends observed at later urban sites may be rooted in preceding centuries, although the underlying reasons for this change are difficult to elucidate. Contributing factors may include the social and religious changes that occurred in the postreformation period, such as the decrease in use of wet nurses; changes in the availability and acceptability of artificial feeding; increased urbanism; and even changes in the socio-economic status of those interred in the Kirk.
\end{abstract}




\section{Introduction}

Infant feeding practices have long been of interest to anthropologists and archaeologists, who use studies of breastfeeding and weaning behaviour to investigate infant and maternal health, birth spacing and its implications for demography, as well as changing societal norms (StuartMacadam and Dettwyler 1995; Van Esterik 2002). In contrast to contemporary Western societies where 'early' weaning (understood here as being completed within the first six months/year of life) is frequently practiced, in modern non-industrialised and 'traditional', natural fertility communities weaning is most commonly completed between 2-3 years (Dettwyler 1995; Dettwyler 2004; Sellen 2001). In most circumstances, infant diets also include complementary liquid and solid foods prior to the cessation of breastfeeding (i.e. before weaning is fully completed), often before the age of 6 months (Sellen 2001). Practices are varied, however, and cultural factors are known to strongly influence the duration of breastfeeding in past and present societies (Dettwyler 2004; Sellen 2007; Stuart-Macadam and Dettwyler 1995).

Primary documentary evidence suggests stark changes in the accepted norms in terms of the timing and nature of weaning in pre-modern Western Europe. By the late $18^{\text {th }}$ and $19^{\text {th }}$ century children are thought to have been weaned earlier than those in the medieval, and earlier, periods. Documentary evidence for these practices is, however, scarce and usually refers to the habits of a small proportion of the population, often the literate upper classes, or consists of physicians' recommendations, which may not have been followed by the general populace (Fildes 1986). Indeed, there are accounts of conflicting practices: for example, in the late $15^{\text {th }}$ century treatise 'Der Rosengarten' the German physician Rösslin notes that while the advice is to suckle a child for two years 'amonge us most commonlye they sucke but one yeare' (English translation from Wickes 1953a: 156). Given the patchiness of the documentary record, additional, independent proxies, such as isotope bioarchaeological approaches, are extremely valuable for reconstructing breastfeeding and weaning practices in past societies.

For Britain, stable isotope datasets demonstrating weaning age and the transition to adult diet now exist for a whole range of archaeological periods: including the Iron Age/Romano-British period, the early and late Anglo-Saxon period, the Middle Ages, and the late $18^{\text {th }} / 19^{\text {th }}$ century (Beaumont et al. 2013; Burt 2013; Fuller et al. 2006b; Fuller et al. 2003; Haydock et al. 2013; Henderson et al. 2014; Jay et al. 2008; Macpherson 2005; Mays et al. 2002; Nitsch et al. 2011; Powell et al. 2014; Privat et al. 2002; Richards et al. 2002). These studies have provided new understandings of life-history traits amongst prehistoric 
populations, and serve to highlight the value of bioarchaeological research on historic populations. Where our understanding of demography is principally record-based, such analyses can bring further insights into a range of human behaviours that cannot always be readily inferred from the study of texts alone. Furthermore, the volume of data generated has allowed broad trends to emerge, such as the potential relationship between increasing urbanism and earlier weaning (Fulminante 2015; Haydock et al. 2013). Such syntheses of disparate datasets are valuable, but often incorporate qualitative estimates rather than quantitative comparisons. Furthermore, there is a distinct geographical bias with all of the investigated populations being from England and the vast majority from the South and especially London, which, because of its size, may not be typical of the majority of towns (Beaumont et al. 2013; Nitsch et al. 2011; Powell et al. 2014, but see Burt et al. 2013 for a study based in the City of York). There are currently no published datasets which analyse weaning behaviour through time at the same site and there is also still a crucial gap in the data in the $16^{\text {th }}$ and $17^{\text {th }}$ centuries, making it difficult to understand long-term diachronic changes. There is, therefore, the need for both further studies and the quantitative synthesis of previously published data to better illuminate continuity and change in weaning age in Britain's past.

The aims of this study were: 1) to extend the chronological, geographical and societal scope of isotope research on infant feeding practices in Britain with a significant new diachronic study and 2) to analyse data, including those from previously published studies, using WARN - an open-source R Package that provides quantitative age estimates for the commencement and completion of weaning based on isotope datasets (Tsutaya and Yoneda 2013). The new dataset from medieval and post-medieval St. Nicholas Kirk, Aberdeen, presented here is the first diachronic investigation of weaning age undertaken at a single site, and the first study undertaken in Scotland, providing important new evidence for weaning age from an urban centre during the medieval and early modern (pre- $19^{\text {th }}$ century) period. Through the quantitative comparison of these new data with previously published data, we examine whether changes in the age of weaning documented in $16^{\text {th }}-18^{\text {th }}$ century historical sources, which laid the foundations for later $19^{\text {th }}$ century and modern societal norms in Britain (Fildes 1986 352-376), are evident in the skeletal samples from St. Nicholas Kirk.

\section{Stable isotopes and infant feeding practices in Archaeology}


The isotope composition of bodily tissues reflects those of the foods ingested during the period of tissue formation. In the case of collagen, a structural protein commonly preserved in archaeological bone, this period can extend over several decades in adults. Ribs are often selected for sampling given their relatively rapid tissue turnover (Sealy et al. 1995). In growing infants and children, new tissue is continuously laid down and the time lag between dietary change and changes in rib collagen isotope values are consequently even shorter, although exact estimates are lacking and probably variable between individuals (Nitsch et al. 2011).

Carbon and nitrogen stable isotope analyses of collagen from archaeological bone is commonplace in modern archaeology, and is often employed to provide evidence of palaeodiet (specifically the main types of dietary protein consumed during life). In the absence of $\mathrm{C}_{4}$ plants, such as in most of Northern Europe prior to the arrival of New World foods, stable carbon isotope values $\left(\delta^{13} \mathrm{C}\right)$ values are mainly used to distinguish between the consumption of marine and terrestrial (C3-plant based) protein (Schoeninger et al. 1983; Tauber 1981). Stable nitrogen isotope $\left(\delta^{15} \mathrm{~N}\right)$ values increase with each step up the food chain, and can therefore be used to determine the trophic level of protein in the diet (e.g. plant protein, versus herbivore or omnivore protein) (Bocherens and Drucker 2003). Because of the large number of trophic steps in marine and aquatic foodchains, $\delta^{15} \mathrm{~N}$ values in aquatic systems tend to be very high (Richards et al. 2001).

While isotopes of a number of different elements have been used to explore past infant feeding practices, by far the most commonly used have been isotopes of nitrogen (but see reviews in Jaouen and Pons 2016, and Tsutaya and Yoneda 2015, for other isotopes). Exclusively breastfed infants are a trophic level above their mothers, leading to ${ }^{15} \mathrm{~N}$ enrichment of newly-forming tissues. During and following weaning, a drop in $\delta^{15} \mathrm{~N}$ occurs. Such patterns have been demonstrated in modern soft tissue studies, where a shift of between 2 and $4 \%$ in nitrogen isotope ratios of keratinous tissues (hair and fingernails) has been observed in breastfeeding infants relative to their mothers (Fogel et al. 1989; Fuller et al. 2006a). This has also been demonstrated in controlled feeding experiments on skeletal tissues of domestic animals (dentinal collagen: Balasse et al. 2001) and on a range of wild species (e.g. dentinal collagen: Fahy et al. 2014; e.g. blood plasma and milk proteins: Jenkins et al. 2001; Polischuk et al. 2001). On the basis of these modern studies, nitrogen (and carbon) isotope measurements of archaeological bone collagen from multiple individuals have been used to infer infant 
feeding and weaning age in a range of archaeological populations (see reviews in Fulminante 2015; Haydock et al. 2013; Tsutaya and Yoneda 2015).

A number of assumptions underlie the application of bulk bone collagen isotope analysis to the estimations of the timing of weaning behaviours. For example, values from buried adult females are taken to be representative of the range of maternal isotope values and offspring in utero/at birth are assumed to the same isotope ratio as their mothers. Postpartum, and following the onset of breastfeeding, it is assumed that a trophic level rise similar to that observed in modern experimental and field studies would be measurable in bone collagen. According to this model, and factoring in a time lag between change in diet and change in the isotope chemistry of newly formed tissue, $\delta^{15} \mathrm{~N}$ values are assumed to peak prior to commencement of weaning and gradually decrease during the subsequent period of supplementary feeding. When breastfeeding ceases (i.e. weaning is complete), the infant values should be similar to the female mean.

These assumptions, combined with data from other published studies, raise a number of issues that may undermine the validity of this approach. For example, elevated $\delta^{15} \mathrm{~N}$ values recorded in foetuses and perinates too young to have been breastfed could be related to short term changes in their mothers' diet or even maternal stress during pregnancy (Beaumont et al. 2015: 443). Similarly, any short-term changes in the mother's bodily $\delta^{15} \mathrm{~N}$ values during the period spent breastfeeding, due to diet or other factors, would influence $\delta^{15} \mathrm{~N}$ values in infant tissues. Furthermore, nutritional or other physiological stresses on the infant itself may also influence infant tissue $\delta^{15} \mathrm{~N}$ values prior to or during weaning (see reviews in Fuller et al. 2005; Reitsema 2013). Given that weaning studies utilising bone collagen rely on data from infants and children who did not survive into adulthood, it is therefore possible that those infants and sub-adults studied in particular experienced atypical feeding or weaning histories (Tsutaya and Yoneda 2015), or were otherwise undergoing physiological stress. Indeed, some recent studies which have sought to address this issue by utilizing dentine serial samples from adult skeletons (i.e. survivors of infancy) in order to reconstruct early-life dietary histories have observed a number of 'survivors' whose isotope signals do not appear to display the 'standard curve' expected for a period of breastfeeding followed by weaning, while non-survivors in the same populations did. This suggests that early life changes in $\delta^{15} \mathrm{~N}$ values do not simply reflect patterns of breastfeeding and weaning but also other aspects of nutritional histories, of infants as well as their mothers, particularly in instances of populations undergoing nutritional stress 
(Beaumont et al. 2013; Beaumont et al. 2015). Correlations between diet and health status has also been inferred in other incremental dentinal studies of other archaeological populations (e.g. Burt 2015). However, the full implications of this for archaeological weaning studies, particularly for populations that did not experience extreme nutritional hardship, are not yet clear, especially since there is a very large body of evidence from modern studies on a number of tissues, including dentinal collagen, that breastfeeding and weaning are usually the overriding factors that best explain variations in infant $\delta^{15} \mathrm{~N}$ (Balasse et al. 2001; Fahy et al. 2014; Fogel et al. 1989; Fuller et al. 2006a; Jenkins et al. 2001; Polischuk et al. 2001). Correlations of $\delta^{15} \mathrm{~N}$ and $\delta^{18} \mathrm{O}$ isotope values in archaeological bone, the latter reflecting breastfeeding but due to different physiological mechanisms (isotopic fractionation of the body water rather than protein metabolism), also provide further support for the link of infant bone collagen $\delta^{15} \mathrm{~N}$ with weaning history (Britton et al. 2015). It should also be noted that pair-wise analyses of incrementally sampled M1 and M2 teeth from adults in another recent study from 19th Century Southwark, London, also appear to confirm early life enrichment in $\delta^{15} \mathrm{~N}$ (related to breastfeeding) is evident in dentinal sections, even in childhood 'survivors' (Henderson et al. 2014). Other studies utilising incremental dentine samples from adults in similar ways have also produced data consistent with breastfeeding and weaning 'signals', including archaeological case studies (e.g. highlighting inter-individual variability amongst a prehistoric popultion from the Central Valley of California, Eerkens et al. 2011) and in experiments using modern samples (e.g. highlighting differences between bottle and breastfed babies, Burt and Garvie-Lok 2013). Nevertheless, the new incremental data now emerging from dentine serial sections from nutritionally-stressed populations do serve as an important reminder to beware of simplistic models and interpretations, and highlights that - while $\delta^{15} \mathrm{~N}$ values in bodily tissues are most commonly related to diet (breastmilk or otherwise) - individual values can be strongly influenced by other factors.

As in other areas of palaeodietary research (e.g. Neolithic diet, see Montgomery et al. 2013), incremental dentinal stable isotope data sets are undoubtedly valuable in investigations of past infant feeding practices, illuminating individual life histories and enhancing resolution achievable, but do not negate the qualities of bone collagen datasets. Given the relative ease of data generation and analysis, far larger sample sizes are normally obtainable using bulk bone collagen. This permits the cross-comparison of greater numbers of individuals from multiple sites over multiple periods. The effectiveness of this approach is reiterated by the diachronically-varying bone collagen datasets which have been produced by a number of 
studies to date, from the Iron Age/Romano-British period to the late $18^{\text {th }} / 19^{\text {th }}$ century (e.g. Fuller et al. 2006b; Jay et al. 2008; Nitsch et al. 2011). While large datasets are an asset, how to meaningfully compare and quantitatively analyse such data remains an issue. While various statistical approaches have been proposed to provide age-estimates for the commencement and completion of weaning based on isotope datasets (Millard 2000; Schurr 1997; Tsutaya and Yoneda 2013), these have been underused in archaeology to date and estimates of age at weaning based on studying plotted data, rather than quantitative estimates, remain common, even in review studies of previously published datasets (e.g. Fulminante 2015; Haydock et al. 2013). A recently proposed model, the R Package WARN, incorporates estimated bone turnover rates and uses a framework of approximate Bayesian computation to calculate the age at the start and end of weaning (R Core Team 2014; Tsutaya and Yoneda 2013). WARN and other statistical approaches, allow the comparison of breastfeeding practices across different archaeological nitrogen isotope datasets to go beyond qualitative estimations, and illuminate continuity and change in previously published datasets from the same region.

\section{Materials and Methods}

\subsection{Aberdeen and St. Nicholas Kirk}

Lying between the Rivers Don and Dee in North-East Scotland, the modern city of Aberdeen comprises several ancient burghs including Aberdeen and Old Aberdeen (Figure 1). By the time of its establishment as a Royal Burgh in the $12^{\text {th }}$ Century, Aberdeen was a growing urban centre with a thriving harbour (Dennison 2002; Johnston and Speirs 2001). Estimated to have had a population of around 3000 in AD 1200, by the later Middle Ages this had risen to around 4500-5000 and by the mid-1 $7^{\text {th }}$ century likely exceeded 8000 (Stell 2002: 108; Tyson 2002: 112), making it a large and important town by the standards of the time. In the late Georgian era, the population was $\sim 17,000$, and at the taking of the first census in 1801 , the population was 27,000, including Aberdeen and Old Aberdeen (Stell 2002: 99; Tyson 2002: 112).

The Kirk of St. Nicholas Uniting as it survives today, was primarily constructed in the $19^{\text {th }}$ century, a composite of the East and West churches (Dennison and Stones 1997; Hunter 1972-74). However, the current Kirk is just one of a number of buildings that have stood at this location since the church's foundation in the late $11^{\text {th }}$ or early $12^{\text {th }}$ century. The dedication to St. Nicholas, the patron saint of sea-faring traders, is unlikely to have been coincidental, reflecting Aberdeen's maritime commerce (Dennison 2002: 6; Johnston and Speirs 2001: 122). 
As Aberdeen grew and prospered in the high medieval period, so did St. Nicholas Kirk and by the end of the Middle Ages (c. 1500), St. Nicholas Kirk was one of the largest burgh churches in Scotland, before being divided into East and West preaching churches following the Reformation (Dennison et al. 2002: 30; Lynch et al. 2002: 292-293).

\subsection{The skeletal assemblage and sample selection}

In 2006, planned development at St. Nicholas led to the extensive excavation of the East Kirk (Figure 2). The earliest structure excavated was an apsidal church, dating from the late $11^{\text {th }}$ century/early $12^{\text {th }}$ century $\mathrm{AD}$, with excavations revealing various phases of later construction and remodelling. During the excavations more than 900 individuals were recorded, along with a very large quantity of disarticulated material (Stones et al. 2008). The skeletons cover a period of more than 800 years, from the late $11^{\text {th }} / 12^{\text {th }}$ century to the $18^{\text {th }}$ century $A D$, with two radiocarbon dates (a single sample of coffin wood, and one of human bone) confirming a late $11^{\text {th }}$ century nascence. The skeletal assemblage is the largest collection excavated from any Scottish medieval burgh, and offers a unique opportunity to study a large burial population from medieval and post-medieval Scotland (Duffy et al. 2008).

The burials include those from the Kirkyard of the late $11^{\text {th }} / 12^{\text {th }}$ century apsidal church and those associated with the mid- and late- $12^{\text {th }}$ century constructions. Although association of some burials with particular periods/building phases was possible, the majority of these individuals were assigned to a broader $12^{\text {th }}-15^{\text {th }}$ century range by the excavators (grouped as 'Phase A'). From 1500, after a phase of demolishing and rebuilding in the mid-late $15^{\text {th }}$ century, burial continued inside the church and the Kirkyard, although post- $15^{\text {th }}$ century burials excavated exclusively originate from the interior of church ('Phase B'; late $15^{\text {th }}$ century to $18^{\text {th }}$ century, primarily $16 / 17^{\text {th }}$ century).

\subsection{Analytical methods and data analysis}

For this study, ribs were selected from sub-adults from Phase A $(n=40)$ and Phase B $(n=27)$, in order to gain a sample distributed across ages from peri- and neonates to $<\sim 18$ years of age. The analysis of the human skeletal assemblage from St. Nicholas Kirk was led by one of the authors (PD), and Glasgow University Archaeological Research Division (GUARD), following standards defined in Buikstra and Ubelaker (1994), and guidelines detailed in 
Brickley and McKinley (2004). Methods used for determining age at death were in accordance with those outlined by Buikstra and Ubelaker (1994), Krogman and Isçan (1986) and Scheuer and Black (2000). Assessment of biological sex in adults was based on differences in male and female pelvic and cranial morphology (Buikstra and Ubelaker 1994), supplemented by metrics taken from various long bones (Bass 1995).

Bone collagen was extracted from ribs using a modified Longin method (Brown et al. 1988; Collins and Galley 1998; Longin 1971) at the University of Aberdeen, following the protocol described in Britton et al. (2012: 170), filtered to the $>30 \mathrm{KDa}$ fraction. Stable carbon and nitrogen isotope measurements were undertaken by continuous-flow isotope ratio mass spectrometry at the University of Reading. Analytical error determined from the repeat measurements of internal and international standards was $\pm 0.2 \%$ o $(1 \sigma)$ or better. The R package WARN was utilised to model data (R Core Team 2014; Tsutaya and Yoneda 2013), along with data from 5 other early Medieval to early modern datasets from 6 previous publications, and default programme parameters were used (see Supplementary Information). In the presentation (and analysis) of data, stable isotope measurements are plotted with the midpoint of age ranges. While nitrogen isotope data are the focus of this paper, carbon isotope data are also presented to aid any relevant dietary interpretation.

\section{Results and Data Interpretation}

Stable nitrogen and carbon isotope data from rib bone collagen from peri-/neo- nates, infants, and sub-adults from Phase A and Phase B at St. Nicholas Kirk are shown in Table 1 and Table 2 respectively. Mean adult female values ( \pm 1 s.d.) for both phases are also shown. Figure 3 presents the nitrogen stable isotope data for the sub-adults from St. Nicholas Kirk alongside the mean $\delta^{15} \mathrm{~N}$ values for adult females (representing maternal values; K. Britton, unpublished data). Results of the WARN model application to the St. Nicholas Kirk data, and data from 5 other early medieval to early modern datasets from 6 previous publications, are summarized in Table S1, details of which are also presented in Figure 4 (including ranges for the commencement (t1) and completion of weaning (t2, including MDEs) from all datasets analysed using the WARN R Package). For each of the case studies, results of applying the WARN model are presented in Figures S2-S8, and described in the caption of each composite image. In Figure 5, the nitrogen stable isotope data for peri-/neo- nates, infants, and sub-adults 
from medieval St. Nicholas Kirk are plotted alongside previously published data from medieval Wharram Percy (data taken from Britton et al. 2015: Table 1).

\subsection{Comparing Phase A and Phase B at St. Nicholas Kirk}

Sub-adult $\delta^{15} \mathrm{~N}$ values from Phase A range from $16.9 \%$ to $9.6 \%$, and from $17.3 \%$ to $12.1 \%$ o in Phase B. Female means in the two phases of the site are similar, at $12.9 \pm 0.9 \%$ o (1 s.d.) (Phase A; $n=17$ ) and $13.5 \pm 0.5 \%$ ( 1 s.d.) (Phase B; $n=19$ ). Sub-adult carbon stable isotope values ranged from $-20.7 \%$ to $-17.6 \%$ (Phase A) and -20.6\% to $-17.6 \%$ (Phase B), with female mean values of $-18.9 \pm 0.6 \%$ ( 1 s.d.) and $-19.2 \pm 0.4 \%$ ( 1 s.d.) respectively.

As shown in Figure 3, in Phase A there is a rapid rise in $\delta^{15} \mathrm{~N}$ values of the infants from St. Nicholas Kirk shortly after birth, with the most elevated values observed between the ages of 1-2 yrs when the ${ }^{15} \mathrm{~N}$-enrichment from adult female to infant tissues is $+2.1-3.0 \%$ (95\% CI, $p=0.963$, see Table S1). After the age of $\sim 2$ yrs, $\delta^{15} \mathrm{~N}$ values show a rapid decline with the majority of values falling within \pm 1 s.d. of the female adult mean after the age of $\sim 2.5$ yrs. The rapid decline in $\delta^{15} \mathrm{~N}$ values may suggest the weaning phase was relatively short (i.e. that period between which an infant is exclusively breastfed and an infant is consuming an 'adult' diet, although, of course, it should be noted that weaning food, or indeed a child's post-weaning diet, may not be the same as an adult's in any given population). Quantitative analysis of the data using the R Package WARN at St. Nicholas Kirk (Table S1) suggests weaning commenced (t1) between the ages of 0.8 and 2.2 yrs and was completed ( $\mathrm{t} 2)$ between the ages of 2.0 and 2.8 yrs in Phase A. This corresponds with historical evidence for weaning practices in the Medieval period (Fildes 1986; Shahar 1990), although is a little later than suggested by documentary evidence for Medieval Aberdeen specifically, based on which Dennison et al. (2002a: 77 ) suggest infants were breastfed until an age of $\sim 1.5$ years. The $t 1$ age range estimate and maximum density estimate or MDE (i.e. the age at which weaning was most likely first initiated) of 1.8 years is also a little late relative to other medieval British sites assessed in this study (see section 4.2).

In Phase $\mathrm{B}$, while $\delta^{15} \mathrm{~N}$ values of sub-adults are similar to Phase $\mathrm{A}$ in terms of mean, minimum and maximum values, there is a different trend with age. As shown in Figure $3, \delta^{15} \mathrm{~N}$ values show an almost steady decline from early infancy (i.e. before the age of 1 year) and, at $\sim 2$ years, they are at the level of the female adult mean. Quantitative analysis using WARN 
suggest weaning commenced soon after birth in Phase B, between the ages of 0.0 and $1.1 \mathrm{yrs}$ (MDE=0.3 yrs), and was completed between the ages of 0.8 and $1.8 \mathrm{yrs}$ (MDE=1.3 yrs). These results suggest not only that weaning commenced earlier in the post-medieval period, but may also hint at differences in complementary feeding practices, with a more gradual decrease in $\delta^{15} \mathrm{~N}$ values observed as opposed to the rapid decrease evident in Phase A (with MDEs being $1.8 \mathrm{yrs}$ and $2.3 \mathrm{yrs}$ for $\mathrm{t} 1$ and $\mathrm{t} 2$ respectively). In both phases, isotope values (following the completion of weaning) are very similar to the respective female mean value, suggesting that fully-weaned children consumed protein from similar sources to female adults.

Both qualitative data description and quantitative analysis using WARN reveal a diachronic shift in nitrogen isotope ratios in bone collagen with age between Phase A and Phase $B$ at St. Nicholas Kirk, suggesting differences in infant feeding practices and both the age at which weaning was commenced and at which it was completed in Medieval vs. post-Medieval Aberdeen. Nevertheless, and while overall trends may thus be apparent, there are a number of aspects of the isotope data that suggest a more complicated picture of contemporary diet and/or highlight other issues that may affect individual values and thus influence the broader data analyses. For example, the mean female isotope values (both $\delta^{15} \mathrm{~N}$ and $\delta^{13} \mathrm{C}$ ) in both phases indicate some marine protein (or possibly anadromous fish, such as salmon) input in the adult female diet. In the case of the infants, some of the most elevated nitrogen values determined in individuals from both Phase A and Phase B correspond with less negative carbon isotope ratios in the same individuals. SK726, SK291, SK653, SK656 and SK270 in Phase A all have nitrogen isotope values in excess of $16 \%$ combined with carbon isotope values higher than $18 \%$. The same is true of SK334, SK325, and SK380 in Phase B. While a 'breastfeeding signal' of less negative $\delta^{13} \mathrm{C}$ values relative to nursing females is expected in tissues prior to weaning (Richards et al. 2002; Wright and Schwarcz 1998; Wright and Schwarcz 1999), these elevated values - combined with ${ }^{15} \mathrm{~N}$-enrichment in bone collagen - may be consistent with a varying proportion of marine protein in the diet of some nursing women and/or marine protein directly in the diet of infants through complementary feeding. In the case of nursing women, these could be long-term individual dietary habits that differ from the contemporary 'average' diet (as indicated by the mean female isotope data), or short-term changes that - while not influencing adult female bone collagen values substantially - can substantially influence the tissue values of breastfeeding children. This highlights the issues inherent in the assumption that female bone collagen isotope data defines the maternal range and can be used as a 'baseline' in isotope studies of breastfeeding and weaning (Beaumont et al. 2015). Instead, it 
underpins that, even in an exclusively breastfed infant, tissue $\delta^{13} \mathrm{C}$ and $\delta^{15} \mathrm{~N}$ are not only the dependent on that infant's 'trophic' status but also its mother's (or wet nurse's) diet or nutritional status over the same time period - which may or may not be representative of her long term, averaged diet. In the case of Phase $\mathrm{B}$, the most elevated $\delta^{13} \mathrm{C}$ and $\delta^{15} \mathrm{~N}$ values were determined in the youngest individual, SK334, a perinate. If it is assumed infants have the same carbon and nitrogen isotope ratios as their mothers at birth (Jay et al. 2008, but see Beaumont et al. 2015), this individual is unlikely to have been breastfed for long enough to have influenced the isotope values of growing tissues, instead making it likely that these elevated values instead reflect short-term maternal dietary habits during pregnancy rather than a 'breastfeeding signal'. Such short-term dietary changes, either during pregnancy or postpartum in breastfeeding women, while not negating the 'breastfeeding effect' could serve to enrich or deplete ${ }^{15} \mathrm{~N}$ in the bone collagen of growing infants (depending on the diet change), skewing any subsequent analysis of weaning age in a population. Short-term nutritional or other physiological stresses, which can influence tissue $\delta^{15} \mathrm{~N}$ values, could also be problematic for the same reasons (Beaumont et al. 2015; Reitsema 2013), although is unlikely in the instances discussed above where elevated $\delta^{15} \mathrm{~N}$ values correspond with less negative $\delta^{13} \mathrm{C}$, suggesting instead short-term changes in diet.

\subsection{Comparison with previously published datasets}

In order to further enable quantitative comparisons and to comment further on possible temporal trends in breastfeeding and weaning practices in Aberdeen and beyond, data from previously published early medieval to post-medieval studies were also modelled using the $\mathrm{R}$ Package WARN (see Figure 4, and Supplementary Information). In comparison with data from earlier British sites (Figure 4), it appears that weaning in medieval Aberdeen occurred substantially earlier than at Anglo-Saxon Berinsfield ( $5^{\text {th }}-7^{\text {th }}$ century; Privat et al. 2002; $2=3.3-$ $7.7 \mathrm{yrs}$ ), although it should be noted that the lengthy $\mathrm{t} 2$ period at Berinsfield may partially be due to the smaller number of infants/children under 10 years $(n=15)$ compared to other sites. Weaning age at late Anglo-Saxon (10 $/ 11^{\text {th }}$ century) Raunds Furnells, however, was more similar to that in medieval Aberdeen (Haydock et al. 2013; $\mathrm{t} 2=1.7-2.7 \mathrm{yrs}$;)

Although skeletal material from the rural site of Wharram Percy dates from the $10^{\text {th }}$ $16^{\text {th }}$ centuries, the dataset used here for comparison (Figure 5) largely dates to c. $12-14^{\text {th }}$ centuries (Britton et al. 2015), and is therefore broadly contemporary to medieval Aberdeen. 
The values observed at Wharram Percy and those at St. Nicholas Kirk vary consistently in all age classes (by $\sim 4 \%$, likely reflecting differences in 'baseline' values and adult dietary habits), however, the trends exhibited by the two datasets are broadly similar. The estimate for completion of weaning at Wharram Percy ( $\mathrm{t} 2=1.4-2.1 \mathrm{yrs})$ is slightly earlier but comparable with medieval Aberdeen, suggesting similar contemporary practices in this period. Weaning age at later medieval Fishergate House (mid- $14^{\text {th }} / \mathrm{mid}-15^{\text {th }}$ century) in the City of York (Burt 2013: 411; $\mathrm{t} 2=1.2-1.8 \mathrm{yrs}, \mathrm{MDE}=1.5 \mathrm{yrs}$ ) is earlier still, completing before either St. Nicholas Kirk (Phase A) or Wharram Percy. By the $14^{\text {th }}$ century York was one of the most populous cities in England, perhaps reiterating the relationship in the later medieval period between increasing urbanism and a reduction in age at weaning already postulated by other researchers (Fulminante 2015; Haydock et al. 2013). However, the later commencement of weaning in Medieval urban Aberdeen relative to rural Wharram Percy (t1 ranges) cannot be explained similarly, and perhaps hint instead at some regional or population-level variations in infant feeding practices during the medieval period.

The data from post-medieval Aberdeen is similar to that seen in $18^{\text {th }}-19^{\text {th }}$ century population from Christ Church, Spitalfields - where weaning commenced before or by $\sim 1$ year of age and complementary feeding ended before or by $\sim 2$ years of age (Nitsch et al. 2011, $\mathrm{t} 1=0.0-1.2 \mathrm{yrs}, \mathrm{t} 2=1.2-2.1 \mathrm{yrs})-$ and amongst contemporary populations in London at Lukin Street and St. Saviour's Almshouse, Southwalk, based on incremental dentinal isotope data (Beaumont et al. 2013; Henderson et al. 2014).

\section{Discussion}

The new data from St Nicholas Kirk fit in well with previous isotope studies and lend further support to the suggestion that a wider diachronic trend towards a reduction in the duration of breastfeeding was at work, not just in England but also in Scotland, and in towns and cities beyond London. The reduction in age at weaning observed between medieval and early modern Aberdeen is consistent with historical sources documenting changes in infant feeding in this period (Fildes 1986), and imply that infant feeding behaviours of the $18^{\text {th }}$ and $19^{\text {th }}$ centuries were established in preceding centuries.

The trends in the isotope data explored here are observable both by visual scrutiny of the data and by their quantitative analysis. Here, this has been done using the R Package WARN (Tsutaya and Yoneda 2013), although this could also potentially be achieved through the use 
of other models (e.g. Millard 2000; Schurr 1997). While each of these models has inbuilt assumptions which could influence their results and the ages at which weaning was inferred to have commenced and completed, the application of any particular model to multiple datasets allows differences between datasets to be quantifiable at least in relative terms. Some assumptions are shared across the different models (e.g. that female average isotope values represent the dietary 'baseline'), and others are specific to certain packages (e.g. the assumption that bone collagen turnover is higher in very young infants, and decreases during sub-adulthood in WARN). As explored above with reference to St. Nicholas Kirk specifically, there are also a number of factors that can influence the nitrogen isotope values of specific individuals and therefore also influence the modelled data, such as short-term dietary changes in the mother during pregnancy or post-partum, or physiological conditions in either mother or child. Other factors, such as the resolution achievable in dating a site or a particular phase, could also limit the comparability of data within and between sites or across different social or chronological groupings. Finally, another factor which is potentially limiting our ability to compare different 'age at weaning' datasets (statistically or otherwise) likely lies in the age determinations. Ageat-weaning studies rely on osteoarchaeological estimates of an individual's age at death; dependent on preservation, such age categories can often be broad; methods for aging skeletal assemblages may vary between research groups; and skeletal age (as opposed to chronological age ) is subject to numerous environmental factors, such as nutritional status. In spite of this and the issues explored above, and the resultant 'noise' that could therefore be inherent in any bulk bone dietary isotope study of infant or adult diet, the diachronic trends observed and described here are historically valid and suggest bone collagen datasets remain a valuable source of information about past breastfeeding and weaning practices alongside other approaches (such as incremental dentine studies).

The causes behind the diachronic differences in breastfeeding and weaning practices in the medieval and post-medieval period, in Aberdeen (as demonstrated in this new dataset) and elsewhere, could be attributable to a range of different factors and require further consideration. Nevertheless, one phenomenon which has previously been suggested as being key to explaining the overall reduction in the period of breastfeeding across this period is the rise in urbanism (see Fulminante 2015; Haydock et al. 2013). Increased urbanism is closely linked to women working outside of the home and earlier weaning ages in modern societies (Huffman 1984; Jelliffe and Jelliffe 1978). The Industrial Revolution may have played a key role in this context, as mothers may have been forced to bring breastfeeding to an early end due to their 
participation in the workforce (Newman and Gowland 2016). However, if exclusively related to the necessity of women working outside the home, one would anticipate clear differences between social classes. These are not seen in the archaeological isotope data. The (likely) lower class women of Lukin Street, London, for example, may well have needed to wean early to return to the workforce. However, those buried in the crypt at Christchurch Spitalfields, a decidedly middle class demographic, would unlikely have had the same motivations and pressures, yet age at weaning was similar between the two sites (Beaumont et al. 2013; Henderson et al. 2014). With regards to St. Nicholas Kirk, it is likely that the Phase B burials were of relatively high status and their age-at-weaning (the earliest seen in any of the datasets analysed here) is also unlikely to have been influenced by the economic need for women to find work outside of the home.

Given that the evidence for earlier weaning extends back to the $16^{\text {th }}$ century and (with Fishergate House) possibly earlier, and, at least in the post-medieval period, appears to transcend social class, other factors must be considered. The social changes that occurred following the Reformation and, in particular, those affecting the role of wet nurses, is one such example. During the late $15^{\text {th }}$ century the first treatises on what would now be considered paediatrics appeared, and provide the first documented objections to wet-nursing, with close associations being drawn between the physical and physiological characteristics of the person feeding the infant and the infant itself (Wickes 1953a: 156). During the mid-16 ${ }^{\text {th }}$ century and into the early $17^{\text {th }}$ century further treatises urged against the use of wet nurses, and the importance of maternal feeding was increasingly stressed (Osborn 1979a; Osborn 1979b). Conversely, breastfeeding was considered unfashionable by the upper classes as well as the emerging merchant and professional classes, as it interfered with social activities, clothing and household management (Stevens et al. 2009) and it has been proposed that those mothers who would have used wet nurses in preceding centuries were less prepared to suckle for long periods themselves (Fildes 1986: 369). While it was not until the $19^{\text {th }}$ century that viable artificial infant feeding systems were available, paps or pulps (panadas), and animal milks were popular (if often nutritionally-poor) alternatives to maternal milk or wet-nursing (Stevens et al. 2009; Wickes 1953b; Wickes 1953c). Where wet nurses were unavailable (socially or economically), and either fashion/personal preference or participation in the labour force limited maternal feeding, these other foods would need to be introduced earlier, lowering age at weaning. While individual motivations may have varied, the reduction in weaning age in the later medieval and early modern period shared across Britain (particularly in contrast to the more lengthy and 
varied practices observed in earlier periods; this paper and Haydock et al. 2013), may yet still be an indirect social consequence of rising urbanism. As well as reinforcing social stratification, these environments created melting-pots for the widespread cultural transmission of ideas within and between major conurbations and created space for shared life-histories and experiences. Further study, particularly of contemporary rural populations, will be key to understanding how pervasive and rapid these social changes were across society as a whole.

\section{Conclusions}

The stable nitrogen isotope data from St. Nicholas Kirk, the first such data to allow diachronic comparisons of weaning age in the same population, provide important new evidence for the history of infant feeding in the British Isles. The data suggest both the age at which weaning commenced and completed changed from the medieval to early modern period in Aberdeen. Isotope data from medieval Aberdeen complement previously published data from medieval England, suggesting that infant feeding practices were broadly similar in different contemporary populations, albeit with perhaps more variability than previously anticipated, as revealed by the WARN computations. Data from post-medieval St. Nicholas Kirk give new insights into early modern period breastfeeding and weaning practices, bridging the gap between previously published studies on medieval and $18^{\text {th }}$ and $19^{\text {th }}$ century populations from the British Isles, and suggesting trends observed at later urban sites may be rooted in preceding centuries. Although further studies on $16^{\text {th }}-18^{\text {th }}$ century assemblages (including rural populations) are clearly required, along with earlier populations, analysis of the St. Nicholas Kirk dataset alongside other datasets using WARN has allowed for the quantification of changes in age-at-weaning in Britain's past, serving to better characterise the general diachronic trends that have been previously described (e.g. Haydock et al. 2013).

While this study clearly demonstrates that bulk bone collagen datasets, particularly combined with quantitative analysis, are of continuing value in the reconstruction of infant feeding practices in the past, a number of (non-statistical) 'outliers' in the datasets from St. Nicholas Kirk highlight that short-term (maternal) dietary changes also likely influence infant dietary isotope values. These data were not excluded from the WARN analyses presented here and their influence has not been quantified for St. Nicholas Kirk or any of the other sites studied. Analysis of incremental samples of dentine from early-forming teeth from individuals from St. Nicholas Kirk could provide additional (and potentially more nuanced) information 
about infant dietary histories in the late medieval and early modern period. Furthermore, sequential sampling of late-forming teeth (e.g. third molars) and hair from adult females (found in some of the burials at St. Nicholas Kirk) could inform on the (isotopic) scale of short-term changes in adult diet at the site which could have influenced infant bulk bone collagen. While quantitative or statistical analysis of such a dataset would be limited compared to the larger datasets obtainable from the analysis of bulk bone collagen, incremental isotopic data would provide valuable information about infant dietary histories on a more individual level. It is perhaps this combined approach - integrating large bone collagen data sets with quantitative analysis, and the individual dietary histories obtainable through incremental analysis - which may prove the be the most informative in future studies of weaning practices in past societies. Other isotopic approaches, such as bulk bone phosphate oxygen (Britton et al. 2015) or calcium (Reynard et al. 2013) may also be useful in confirming and further characterising the diachronic trends observed here.

The underlying reasons for the changes in age-at-weaning described in this study are, however, difficult to elucidate, although contributing factors may include the social and religious changes that occurred in the post-Reformation period, such as the decrease in use of wet nurses; changes in the availability and acceptability of artificial feeding; increased urbanism; and - in the case of Aberdeen - even changes in the socio-economic status of those interred in the Kirk themselves. Significantly, the WARN-calculated changes in $\mathrm{t} 1$ and $\mathrm{t} 2$ ranges from St. Nicholas Kirk, combined with previously published studies, tentatively suggest that - although there are some variations - the reduction in age-at-weaning in the later medieval and early modern period likely transcended social class. Although socio-economic status would undoubtedly play a key role in individual decisions surrounding infant feeding and nutrition, these data indicate motivations were unlikely to have been purely economic in growing urban centres, and instead may be rooted in religious or socio-cultural expectations, standards and fashions. It can be speculated that as well as creating new systems for, and reinforcements of, social stratification, the social melting-pots of growing urban environments may have themselves accelerated transference of these new norms.

\section{Acknowledgements}

This work partially supported by a small grant from the Royal Society of Edinburgh to KB, in association with the Mither Kirk Project. Special thanks to John Edwards and Aberdeen City 
Council; Chris Croly and Jeff Oliver (Aberdeen); Jackson Armstrong and William Hepburn (Aberdeen; https://aberdeenregisters.org/); and Takumi Tsutaya (Kyoto University). 


\section{References}

Balasse M, Bocherens H, Mariotti A, and Ambrose SH. 2001. Detection of dietary changes by intra-tooth carbon and nitrogen isotopic analysis: an experimental study of dentine collagen of cattle (Bos taurus). J Archaeol Sci 28:235-245.

Bass WM. 1995. Human osteology: a laboratory and field manual. Columbia: Missouri Archaeological Society.

Beaumont J, Gledhill A, Lee-Thorp J, and Montgomery J. 2013. Childhood diet: A closer examination of the evidence from dental tissues using stable isotope analysis of segmental human dentine. Archaeometry 55(2):277-295.

Beaumont J, Montgomery J, Buckberry J, and Jay M. 2015. Infant mortality and isotopic complexity: New approaches to stress, maternal health, and weaning. Am J Phys Anthropol 157(3):441-457.

Bocherens H, and Drucker D. 2003. Trophic Level Isotopic Enrichment of Carbon and Nitrogen in Bone Collagen: Case Studies from Recent and Ancient Terrestrial Ecosystems. International Journal of Osteoarchaeology 13:46-53.

Brickley M, and McKinley JI. 2004. Guidelines to the Standards for Recording Human Remains. BABAO/ IFA Technical Paper no 7.

Britton K, Fuller BT, Tutken T, Mays S, and Richards MP. 2015. Oxygen isotope analysis of human bone phosphate evidences weaning age in archaeological populations. Am J Phys Anthropol 157(2):226-241.

Britton K, Gaudzinski-Windheuser S, Roebroeks W, Kindler L, and Richards MP. 2012. Stable isotope analysis of well-preserved 120,000-year-old herbivore bone collagen from the Middle Palaeolithic site of Neumark-Nord 2, Germany reveals niche separation between bovids and equids. Palaeogeography, Palaeoclimatology, Palaeoecology 333-334:168-177.

Brown TA, Nelson DE, Vogel JS, and Southon JR. 1988. Improved collagen extraction by modified Longin method. Radiocarbon 30(2):171-177.

Buikstra JE, and Ubelaker DH. 1994. Standards for data collection from human skeletal remains. Fayetteville: Arkansas Archaeological Survey.

Burt NM. 2013. Stable isotope ratio analysis of breastfeeding and weaning practices of children from medieval Fishergate House York, UK. Am J Phys Anthropol 152(3):407-416. 
Burt NM. 2015. Individual dietary patterns during childhood: an archaeological application of a stable isotope microsampling method for tooth dentin. J Archaeol Sci 53:277290.

Burt NM, and Garvie-Lok S. 2013. A new method of dentine microsampling of deciduous teeth for stable isotope ratio analysis. J Archaeol Sci 40(11):3854-3864.

Collins MJ, and Galley P. 1998. Towards an optimal method of archaeological collagen extraction: the influence of $\mathrm{pH}$ and grinding. Ancient Biomolecules 2:209-222.

Dennison EP. 2002. Introduction: Aberdeen before Aberdeen. In: Dennison EP, Ditchburn D, and Lynch M, editors. Aberdeen before 1800: A new history. East Linton: Tuckwell Press.

Dennison EP, Simpson AT, and Simpson GG. 2002. The growth of two towns. In: Dennison EP, Ditchburn D, and Lynch M, editors. Aberdeen before 1800: A new history. East Linton: Tuckwell Press. p 13-43.

Dennison EP, and Stones J. 1997. Historic Aberdeen: the archaeological implications of development: Scottish Cultural Press.

Dettwyler KA. 1995. A time to wean: the hominid blueprint for the natural age of weaning in modern human populations. In: Stuart-Macadam P, and Dettwyler KA, editors. Breastfeeding: Biocultural Perspectives. New York: Aldine De Gruyter.

Dettwyler KA. 2004. When to wean: biological versus cultural perspectives. Clinical Obstetrics and Gynecology 47:712-723.

Duffy P, Arabaolaza I, and Kilpatrick M. 2008. Draft report: The human remains from the St. Nicholas Uniting, Aberdeen. Unpublished GUARD osteoarchaeological report.

Eerkens JW, Berget AG, and Bartelink EJ. 2011. Estimating weaning and early childhood diet from serial micro-samples of dentin collagen. J Archaeol Sci 38(11):3101-3111.

Fahy GE, Richards MP, Fuller BT, Deschner T, Hublin J-J, and Boesch C. 2014. Stable nitrogen isotope analysis of dentine serial sections elucidate sex differences in weaning patterns of wild chimpanzees (Pan troglodytes). Am J Phys Anthropol 153(4):635-642.

Fildes VA. 1986. Breasts, bottles and babies: a history of infant feeding. Edinburgh: Edinburgh University Press.

Fogel ML, Tuross N, and Owsley D. 1989. Nitrogen isotope tracers of human lactation in modern and archaeological populations. Annual report of the Director, Geophysical Laboratory, 1988-1989. Washington, DC: Carnegie Institution of Washington. p 111116. 
Fuller BT, Fuller JL, Harris DA, and Hedges REM. 2006a. Detection of breastfeeding and weaning in modern human infants with carbon and nitrogen stable isotope ratios. Am J Phys Anthropol 129(2):279-293.

Fuller BT, Fuller JL, Sage NE, Harris DA, O'Connell TC, and Hedges REM. 2005. Nitrogen balance and $\delta^{15} \mathrm{~N}$ : why you're not what you eat during nutritional stress. Rapid Commun Mass Spectrom 19:2497-2506.

Fuller BT, Molleson TI, Harris DA, Gilmour LT, and Hedges REM. 2006b. Isotopic Evidence for Breastfeeding and Possible Adult Dietary Differences from Late/SubRoman Britain. Am J Phys Anthropol 129(1):45-54.

Fuller BT, Richards MP, and Mays SA. 2003. Stable carbon and nitrogen isotope variations in tooth dentine serial sections from Wharram Percy. J Archaeol Sci 30(12):16731684.

Fulminante F. 2015. Infant Feeding Practices in Europe and the Mediterranean from Prehistory to the Middle Ages: A Comparison between the Historical Sources and Bioarchaeology. Childhood in the Past 8(1):24-47.

Haydock H, Clarke L, Craig-Atkins E, Howcroft R, and Buckberry J. 2013. Weaning at Anglo-Saxon Raunds: Implications for changing breastfeeding practice in Britain over two millennia. Am J Phys Anthropol 151:604-612.

Henderson RC, Lee-Thorp J, and Loe L. 2014. Early life histories of the London poor using $\delta 13 \mathrm{C}$ and $\delta 15 \mathrm{~N}$ stable isotope incremental dentine sampling. Am J Phys Anthropol 154(4):585-593.

Huffman SL. 1984. Determinants of breastfeeding in developing countries: overview and policy implications. Stud Fam Plann 15:170-183.

Hunter J. 1972-74. The Church of St. Nicholas, Aberdeen. Proceedings of the Society of Antiquaries of Scotland 105:236-247.

Jaouen K, and Pons M-L. 2016. Potential of non-traditional isotope studies for bioarchaeology. Archaeological and Anthropological Sciences:1-16.

Jay M, Fuller BT, Richards MP, Knusel CJ, and King SS. 2008. Iron age breastfeeding practices in Britain: Isotopic evidence from Wetwang Slack, East Yorkshire. Am J Phys Anthropol 136(3):327-337.

Jelliffe DB, and Jelliffe EFB. 1978. Human Milk in the Modern World. Oxford: Oxford University Press. 
Jenkins SG, Partridge ST, Stephenson TR, Farley SD, and Robbins CT. 2001. Nitrogen and carbon isotope fractionation between mothers, neonates, and nursing offspring. Oecologia 129:336-341.

Johnston A, and Speirs D. 2001. Documentary Research. In: Cameron A, and Stones JA, editors. Aberdeen: an in-depth view of the city's past. Edinburgh: Society of Antiquaries of Scotland.

Krogman WM, and Isçan MY. 1986. The human skeleton in forensic medicine. Springfield: Charles C. Thomas.

Longin R. 1971. New method of collagen extraction for radiocarbon dating. Nature 230:241242.

Lynch M, DesBrisay G, and Pittock MGH. 2002. The faith of the people. In: Dennison EP, Ditchburn D, and Lynch M, editors. Aberdeen before 1800: A new history. East Linton: Tuckwell Press. p 289-308.

Macpherson PM. 2005. Tracing Change: An Isotopic Investigation of Anglo-Saxon Childhood Diet. Department of Archaeology, University of Sheffield: Unpublished PhD Thesis.

Mays SA, Richards MP, and Fuller BT. 2002. Bone stable isotope evidence for infant feeding in mediaeval England. Antiquity 76(293):654-656.

Millard AR. 2000. A model for the effect of weaning on nitrogen isotope ratios in humans. In: Goodfriend GA, Collins MJ, Macko SA, and Wehmiller JF, editors. Perspectives in amino acid and protein geochemistry. New York: Oxford University Press. p 5159.

Montgomery J, Beaumont J, Jay M, Keefe K, Gledhill AR, Cook GT, Dockrill SJ, and Melton ND. 2013. Strategic and sporadic marine consumption at the onset of the Neolithic: increasing temporal resolution in the isotope evidence. Antiquity 87(338):1060-1072.

Newman SL, and Gowland RL. 2016. Dedicated followers of fashion? Bioarchaeological perspectives on socio-economic status, inequality, and health in urban children from the Industrial Revolution (18th - 19th C), England.

Nitsch EK, Humphrey LT, and Hedges REM. 2010. The effect of parity status on $\delta 15 \mathrm{~N}$ : looking for the "pregnancy effect" in 18th and 19th century London. J Archaeol Sci 37(12):3191-3199. 
Nitsch EK, Humphrey LT, and Hedges REM. 2011. Using stable isotope analysis to examine the effect of economic change on breastfeeding practices in Spitalfields, London, UK. Am J Phys Anthropol 146:619-628.

Osborn ML. 1979a. The rent breasts. Part II. Midwife Health Visit Community Nurse 15(9):347-348.

Osborn ML. 1979b. The rent breasts: a brief history of wet-nursing. Midwife Health Visit Community Nurse 15(8):302-306.

Polischuk SC, Hobson KA, and Ramsay MA. 2001. Use of stable-carbon and -nitrogen isotopes to assess weaning and fasting in female polar bears and their cubs. Can J Zool 79:499-511.

Powell LA, Redfern RC, and Millard AR. 2014. Infant feeding practices in Roman London: the isotopic evidence. In: Carroll PM, and Graham E-J, editors. Infant health and death in Roman Italy and beyond. Portsmouth, RI: Journal of Roman Archaeology Suppl. 96. p 89-110.

Privat KL, O'Connell TC, and Richards MP. 2002. Stable isotope analysis of human and faunal remains from the Anglo-Saxon cemetery at Berinsfield, Oxfordshire: Dietary and social implications. J Archaeol Sci 29(7):779-790.

R Core Team. 2014. R: A language and environment for statistical computing. R Foundation for Statistical Computing, Vienna, Austria.: http://www.R-project.org/.

Reitsema LJ. 2013. Beyond diet reconstruction: Stable isotope applications to human physiology, health, and nutrition. Amer J Hum Biol 25(4):445-456.

Reynard LM, Pearson JA, Henderson GM, and Hedges REM. 2013. Calcium isotopes in juvenile milk-consumers. Archaeometry 55(5):946-957.

Richards MP, Mays S, and Fuller BT. 2002. Stable carbon and nitrogen isotope values of bone and teeth reflect weaning age at the Medieval Wharram Percy site, Yorkshire, UK. Am J Phys Anthropol 119(3):205-210.

Richards MP, Pettitt PB, Stiner MC, and Trinkaus E. 2001. Stable isotope evidence for increasing dietary breadth in the European mid-Upper Paleolithic. Proc Natl Acad Sci U S A 98(11):6528-6532.

Scheuer L, and Black S. 2000. Developmental juvenile osteology. London: Academic Press. Schoeninger MJ, DeNiro MJ, and Tauber H. 1983. Stable nitrogen isotope ratios of bone collagen reflect marine and terrestrial components of prehistoric human diet. Science 220:1381-1383. 
Schurr MR. 1997. Stable Nitrogen Isotopes as Evidence for the Age of Weaning at the Angel Site: A Comparison of Isotopic and Demographic Measures of Weaning Age. J Archaeol Sci 24(10):919-927.

Sealy J, Armstrong R, and Schrire C. 1995. Beyond lifetime averages: tracing life histories through isotopic analysis of different calcified tissues from archaeological human skeletons. Antiquity 69:290-300.

Sellen DW. 2001. Comparison of infant feeding patterns reported for nonindustrial populations with current recommendations. J Nutr 131:2707-2715.

Sellen DW. 2007. Evolution of infant and young child feeding: implications for contemporary public health. Annu Rev Nutr 27:123-148.

Shahar S. 1990. Childhood in the Middle Ages. London: Routledge.

Stell GP. 2002. Housing in the two towns. In: Dennison EP, Ditchburn D, and Lynch M, editors. Aberdeen before 1800: A new history. East Linton: Tuckwell Press. p 70-96.

Stevens EE, Patrick TE, and Oickler R. 2009. A history of infant feeding. The Journal of Perinatal Education 18(2):32-39.

Stones J, Croly CP, and Cameron A. 2008. East Kirk of St. Nicholas Project: Intial Report (second edition). Aberdeen: Aberdeen City Council Archaeology Unit.

Stuart-Macadam P, and Dettwyler KA. 1995. Breastfeeding: biocultural perspectives. New York: Aldine De Gruyter.

Tauber H. 1981. 13C evidence for dietary habits of prehistoric man in Denmark. Nature 292(5821):332-333.

Tsutaya T, and Yoneda M. 2013. Quantitative Reconstruction of Weaning Ages in Archaeological Human Populations Using Bone Collagen Nitrogen Isotope Ratios and Approximate Bayesian Computation. PLoS ONE 8(8):e72327.

Tsutaya T, and Yoneda M. 2015. Reconstruction of breastfeeding and weaning practices using stable isotope and trace element analyses: A review. Am J Phys Anthropol $156: 2-21$.

Tyson RE. 2002. People in the two towns. In: Dennison EP, Ditchburn D, and Lynch M, editors. Aberdeen before 1800: A new history. East Linton: Tuckwell Press. p 70-96.

Van Esterik P. 2002. Contemporary Trends in Infant Feeding Research. Annu Rev Anthrop $31(1): 257-278$.

Wickes IG. 1953a. A History of Infant Feeding: Part I. Primitive Peoples, Ancient Works, Renaissance Writers. Arch Dis Child 28(138):151-158. 
Wickes IG. 1953b. A History of Infant Feeding: Part II. Seventeenth and Eighteenth Centuries. Arch Dis Child 28(139):232-240.

Wickes IG. 1953c. A History of Infant Feeding: Part III. Eighteenth and Nineteenth Century Writers. Arch Dis Child 28(140):332-340.

Wright LE, and Schwarcz HP. 1998. Stable carbon and oxygen isotopes in human tooth enamel: Identifying breastfeeding and weaning in prehistory. Am J Phys Anthropol 106(1):1-18.

Wright LE, and Schwarcz HP. 1999. Correspondence between stable carbon, oxygen, and nitrogen isotopes in human tooth enamel and dentine: Infant diets and weaning at Kaminaljuyu. J Archaeol Sci 26:1159-1170. 


\section{Figures:}

Figure 1: Location of Aberdeen, including a map of Aberdeen showing position of St. Nicholas Kirk today (A); and of Old and New Aberdeen, c. 1500 (B) showing St. Nicholas Kirk, other contemporary buildings and ecclesiastical establishments (adapted from Dennison et al. 2002: 20, Figure 1.2).

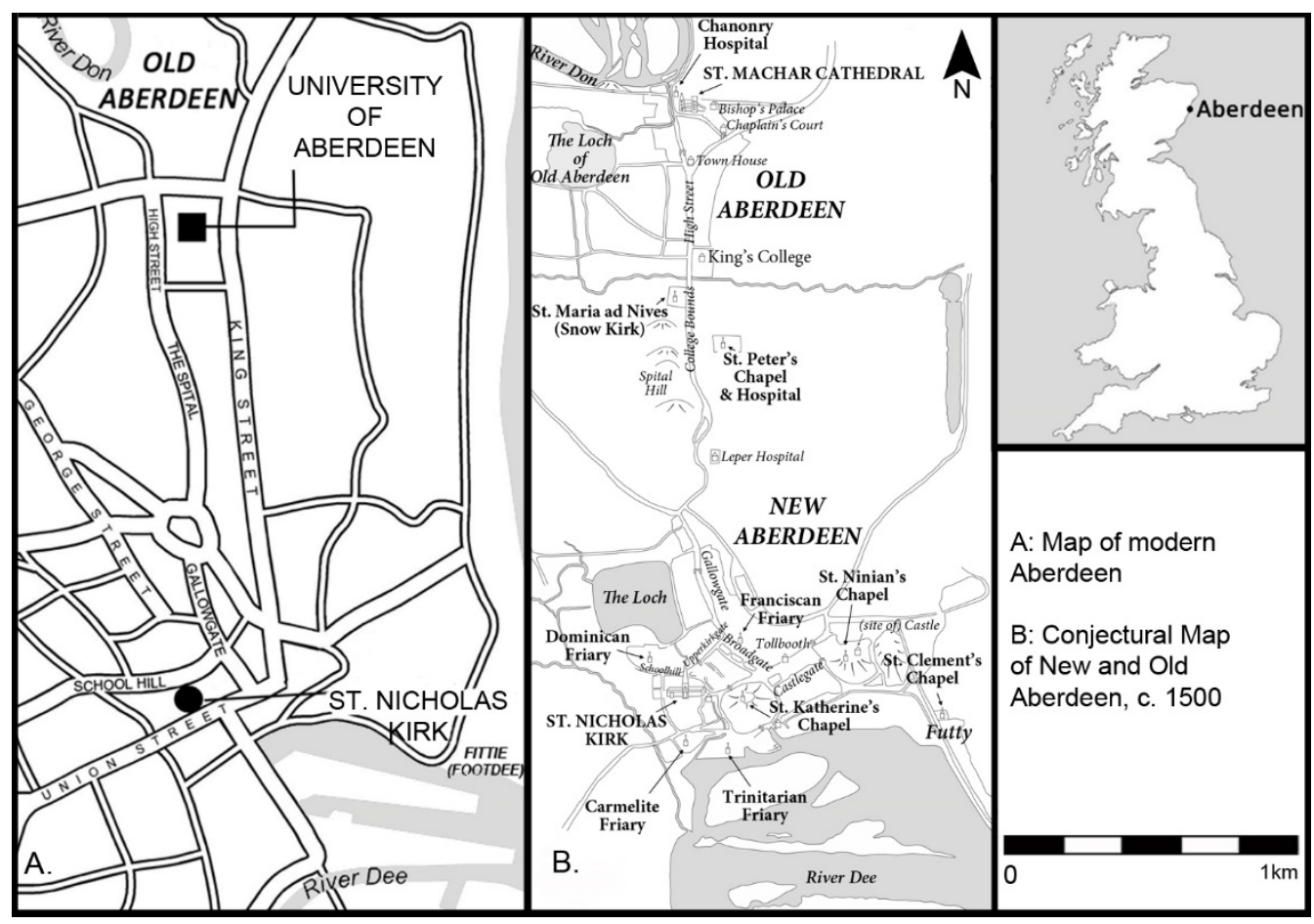


Figure 2: Plan of various architectural features of different building phases determined during the 2006 excavation of the East Kirk of St. Nicholas, Aberdeen, with inset showing the overall plan of the East and West Kirks (adapted from Stones et al. 2008: 11).

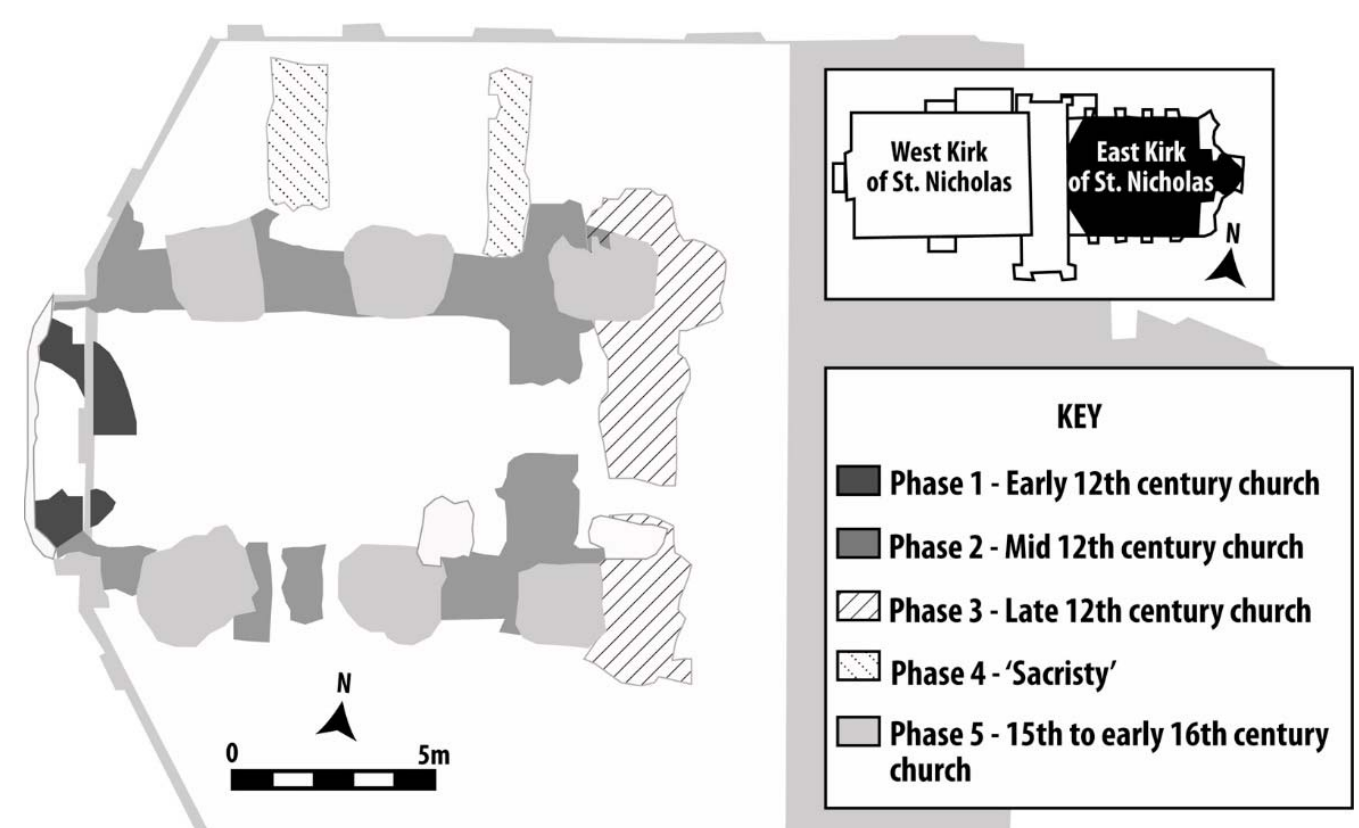


Figure 3: Stable nitrogen isotope data for peri-/neo- nates, infants, and sub-adults from medieval (Phase A) and post-medieval (Phase B) at St. Nicholas Kirk, Aberdeen. Mean adult female values ( \pm 1 s.d.) from each phase are also shown (K. Britton, unpublished data).

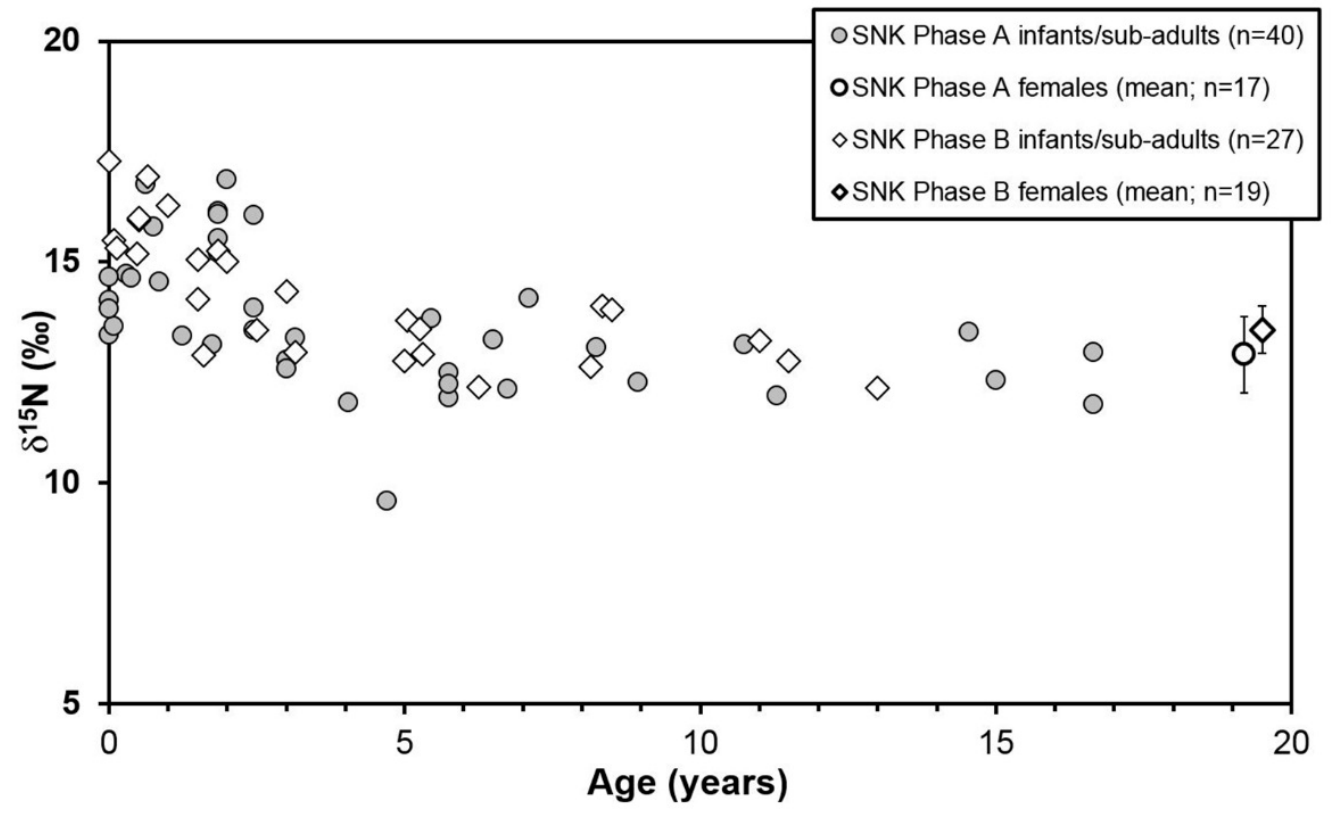


Figure 4: Ranges for the commencement ( $\mathrm{t} 1)$ and completion of weaning ( $\mathrm{t} 2$, including MDEs) from all datasets analysed using the WARN R Package (see Supplementary Material). Sites and data sources are: Berinsfield, Oxfordshire (Privat et al. 2002); Raunds Furnells, Northamptonshire (Haydock et al. 2013); Wharram Percy, Yorkshire (Britton et al. 2015); Fishergate House, York (Burt 2013); Spitalfields, London (Nitsch et al. 2010; Nitsch et al. 2011) and St. Nicholas Kirk, Aberdeen (this study).

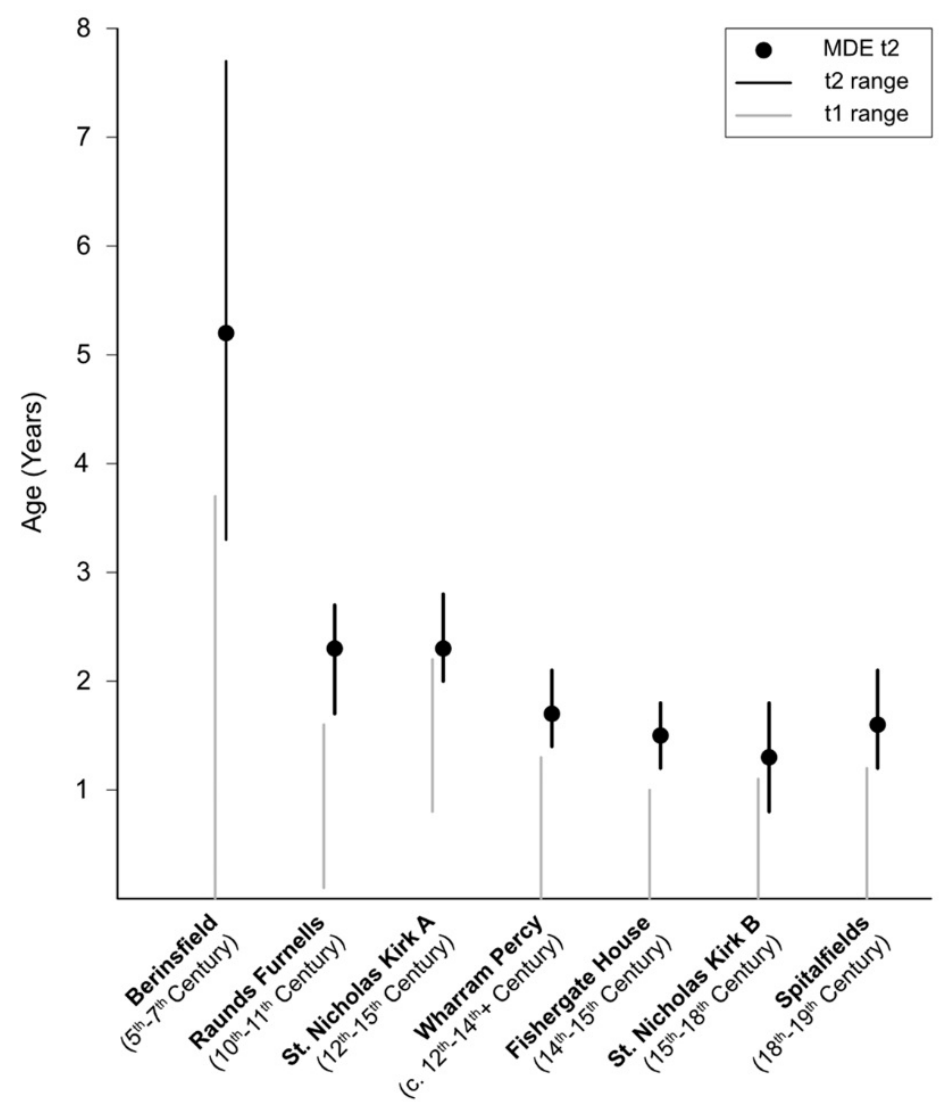


Figure 5: Nitrogen stable isotope data for peri-/neo- nates, infants, and sub-adults from medieval St. Nicholas Kirk. Mean adult female value ( \pm 1 s.d.) is shown (K Britton, unpublished data), along with previously published data from medieval Wharram Percy (data taken from Britton et al. 2015: Table 1).

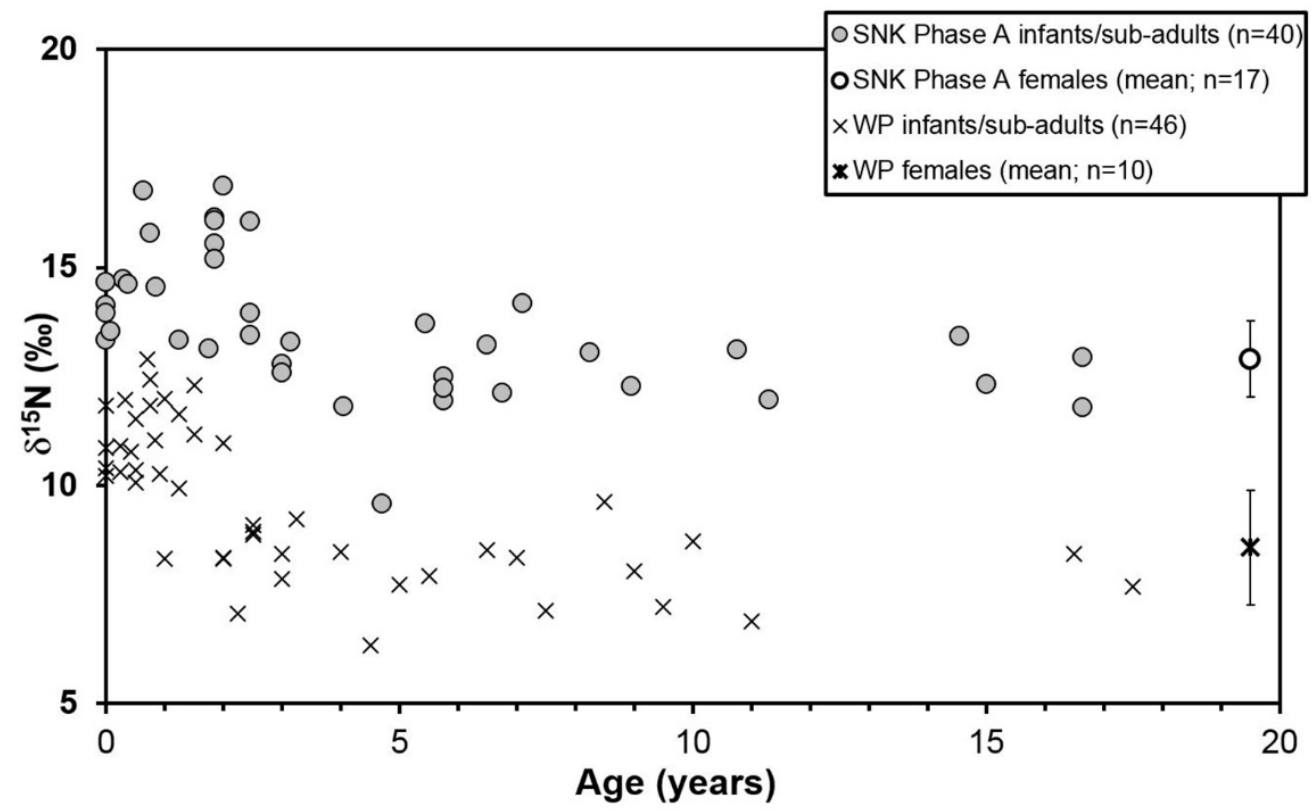


Table 1: Stable nitrogen and carbon isotope data from rib bone collagen from peri-/neo- nates, infants, and sub-adults from Phase A at St. Nicholas Kirk, Aberdeen. Mean adult female values ( \pm 1 s.d.) are also shown.

\begin{tabular}{|c|c|c|c|c|c|c|c|c|c|}
\hline Skeleton No. & Age & $\begin{array}{l}\text { Midpoint } \\
\text { Age (yrs) }\end{array}$ & $\begin{array}{l}\text { Main } \\
\text { Phase }\end{array}$ & $\begin{array}{c}\text { Sub- } \\
\text { Phase }\end{array}$ & $\begin{array}{l}\delta^{13} \mathrm{C} \\
(\% \circ)\end{array}$ & $\begin{array}{l}\delta^{15} N \\
(\% \circ)\end{array}$ & C \% & $\mathbf{N} \%$ & $\mathrm{C}: \mathbf{N}$ \\
\hline 902 & $0 \pm 2$ months & 0.00 & $\mathrm{~A}$ & 1 & -19.3 & 13.3 & 46.7 & 16.9 & 3.2 \\
\hline 911 & $0 \pm 2$ months & 0.00 & $\mathrm{~A}$ & 1 & -18.3 & 14.1 & 45.8 & 16.8 & 3.2 \\
\hline 451 & $0 \pm 2$ months & 0.00 & A & $2-3$ & -18.4 & 14.7 & 45.0 & 16.5 & 3.2 \\
\hline 844 & 8-9 months (in utero) to birth & 0.00 & A & $2-3$ & -19.0 & 13.9 & 45.9 & 16.7 & 3.2 \\
\hline 286 & $0-2$ months & 0.08 & $\mathrm{~A}$ & 1 & -18.6 & 13.5 & 46.0 & 16.7 & 3.2 \\
\hline 907 & c. 2-5 months & 0.29 & $\mathrm{~A}$ & 1 & -18.6 & 14.7 & 46.1 & 16.7 & 3.2 \\
\hline 912 & 3-6 months & 0.38 & $\mathrm{~A}$ & 1 & -18.2 & 14.6 & 46.2 & 16.8 & 3.2 \\
\hline 726 & 5-10 months & 0.63 & $\mathrm{~A}$ & $2-3$ & -17.7 & 16.8 & 45.8 & 16.9 & 3.2 \\
\hline 269 & $0.5-1$ years & 0.75 & A & 1 & -18.6 & 15.8 & 46.1 & 17.0 & 3.2 \\
\hline 922 & 0.8-0.9 years & 0.85 & A & 1 & -18.6 & 14.5 & 45.2 & 16.2 & 3.2 \\
\hline 895 & $1-1.5$ years & 1.25 & $\mathrm{~A}$ & 1 & -19.5 & 13.3 & 46.6 & 17.1 & 3.2 \\
\hline 685 & $1-2.5$ years & 1.75 & $\mathrm{~A}$ & $2-3$ & -19.3 & 13.1 & 45.7 & 17.0 & 3.1 \\
\hline 291 & 1.8-1.9 years & 1.85 & $\mathrm{~A}$ & 1 & -17.8 & 16.1 & 46.6 & 17.1 & 3.2 \\
\hline 300 & 1.8-1.9 years & 1.85 & $\mathrm{~A}$ & 1 & -18.1 & 15.5 & 45.7 & 16.5 & 3.2 \\
\hline 302 & 1.8-1.9 years & 1.85 & A & 1 & -18.9 & 15.2 & 46.0 & 16.6 & 3.2 \\
\hline 653 & 1.8-1.9 years & 1.85 & $\mathrm{~A}$ & $2-3$ & -17.9 & 16.1 & 45.3 & 16.8 & 3.2 \\
\hline 656 & c. $1-3$ years & 2.00 & A & $2-3$ & -17.8 & 16.9 & 45.3 & 16.8 & 3.1 \\
\hline 270 & 2.4-2.5 years & 2.45 & A & 1 & -17.6 & 16.1 & 45.5 & 16.5 & 3.2 \\
\hline 456 & 2.4-2.5 years & 2.45 & $\mathrm{~A}$ & $2-3$ & -19.3 & 13.5 & 44.7 & 16.8 & 3.1 \\
\hline 687 & 2.4-2.5 years & 2.45 & $\mathrm{~A}$ & $2-3$ & -18.4 & 14.0 & 44.7 & 16.6 & 3.1 \\
\hline 655 & c. 3 years & 3.00 & A & $2-3$ & -20.3 & 12.8 & 46.4 & 17.1 & 3.2 \\
\hline
\end{tabular}




\begin{tabular}{|c|c|c|c|c|c|c|c|c|c|}
\hline 669 & 3 years \pm 12 months & 3.00 & $\mathrm{~A}$ & $2-3$ & -19.2 & 12.6 & 46.4 & 17.0 & 3.2 \\
\hline 577 & 3.1-3.2 years & 3.15 & A & $2-3$ & -18.9 & 13.3 & 45.8 & 16.5 & 3.2 \\
\hline 279 & 4-4.1 years & 4.05 & $\mathrm{~A}$ & 1 & -19.6 & 11.8 & 46.4 & 17.0 & 3.2 \\
\hline 840 & 4.5-4.9 years & 4.70 & A & 1 & -20.7 & 9.6 & 47.0 & 17.1 & 3.2 \\
\hline 457 & 5.4-5.5 years & 5.45 & $\mathrm{~A}$ & $2-3$ & -19.2 & 13.7 & 45.1 & 16.5 & 3.2 \\
\hline 306 & 5.4-6.1 years & 5.75 & $\mathrm{~A}$ & 1 & -19.7 & 11.9 & 42.4 & 13.6 & 3.6 \\
\hline 915B & 5.4-6.1 years & 5.75 & $\mathrm{~A}$ & 1 & -19.2 & 12.5 & 45.1 & 16.3 & 3.2 \\
\hline 455 & 5.4-6.1 years & 5.75 & $\mathrm{~A}$ & $2-3$ & -20.6 & 12.2 & 45.3 & 16.3 & 3.2 \\
\hline 236 & 6-7 years & 6.50 & $\mathrm{~A}$ & 1 & -18.2 & 13.2 & 46.5 & 16.7 & 3.3 \\
\hline 299 & 6.5-7 years & 6.75 & $\mathrm{~A}$ & 1 & -19.0 & 12.1 & 46.7 & 16.9 & 3.2 \\
\hline 565 & $6.5-7.7$ years & 7.10 & $\mathrm{~A}$ & $2-3$ & -18.0 & 14.2 & 44.9 & 16.2 & 3.2 \\
\hline 568 & 7.7-8.8 years & 8.25 & A & $2-3$ & -19.1 & 13.1 & 46.2 & 17.0 & 3.2 \\
\hline 671 & 7.5-10.4 years & 8.95 & $\mathrm{~A}$ & $2-3$ & -19.4 & 12.3 & 44.9 & 16.2 & 3.2 \\
\hline 651 & 9.5-12 years & 10.75 & $\mathrm{~A}$ & $2-3$ & -18.6 & 13.1 & 46.2 & 16.9 & 3.2 \\
\hline 483 & 9.4-13.2 years & 11.30 & $\mathrm{~A}$ & $2-3$ & -19.4 & 12.0 & 45.0 & 16.3 & 3.2 \\
\hline 615 & $13.5-16.2$ years & 14.55 & $\mathrm{~A}$ & $2-3$ & -18.8 & 13.4 & 44.7 & 16.2 & 3.2 \\
\hline 611 & c. 15 years & 15.00 & $\mathrm{~A}$ & $2-3$ & -18.7 & 12.3 & 45.7 & 16.9 & 3.2 \\
\hline 847 & 16.4-16.9 years & 16.65 & A & 1 & -19.7 & 11.8 & 46.8 & 17.0 & 3.2 \\
\hline 791 & 16.4-16.9 years & 16.65 & A & $2-3$ & -18.8 & 12.9 & 46.1 & 17.0 & 3.2 \\
\hline Adult female (mean; $n=17$ ) & & & $A$ & & -18.9 & 12.9 & & & \\
\hline (1 stdev) & & & & & 0.6 & 0.9 & & & \\
\hline
\end{tabular}


Table 2: Stable nitrogen and carbon isotope data from rib bone collagen for peri-/neo- nates, infants, and sub-adults from Phase B at St. Nicholas Kirk, Aberdeen. Mean adult female values ( \pm 1 s.d.) are also shown.

\begin{tabular}{|c|c|c|c|c|c|c|c|c|c|}
\hline Skeleton No. & Age & $\begin{array}{l}\text { Midpoint } \\
\text { Age (yrs) }\end{array}$ & $\begin{array}{l}\text { Main } \\
\text { Phase }\end{array}$ & $\begin{array}{l}\text { Sub- } \\
\text { Phase }\end{array}$ & $\begin{array}{l}\delta^{13} \mathbf{C} \\
(\%)\end{array}$ & $\begin{array}{l}\delta^{15} \mathbf{N} \\
(\% \circ)\end{array}$ & $\mathrm{C} \%$ & $\mathbf{N} \%$ & $\mathrm{C}: \mathrm{N}$ \\
\hline 334 & 37-41 weeks (in utero) & 0.00 & $\mathrm{~B}$ & $4 \mathrm{~B}$ & -17.8 & 17.3 & 45.6 & 16.7 & 3.2 \\
\hline 494 & 40-44 weeks (in utero) & 0.08 & $\mathrm{~B}$ & $4 \mathrm{~B}$ & -18.6 & 15.5 & 46.3 & 16.9 & 3.2 \\
\hline 65 & 0-3 months & 0.13 & $\mathrm{~B}$ & $4 \mathrm{~B}$ & -19.3 & 15.3 & 45.9 & 16.7 & 3.2 \\
\hline 172 & 5-6.5 months & 0.48 & $\mathrm{~B}$ & $4 \mathrm{~B}$ & -19.5 & 15.2 & 45.7 & 16.6 & 3.2 \\
\hline 377 & $6 \pm 3$ months & 0.50 & $\mathrm{~B}$ & $4 \mathrm{~A}$ & -18.1 & 16.0 & 45.6 & 16.8 & 3.2 \\
\hline 56 & 3-9 months & 0.50 & $\mathrm{~B}$ & $4 \mathrm{~B}$ & -18.5 & 16.0 & 45.6 & 16.8 & 3.2 \\
\hline 325 & c. 8 months & 0.66 & $\mathrm{~B}$ & $4 \mathrm{~B}$ & -17.6 & 16.9 & 44.9 & 16.7 & 3.1 \\
\hline 149 & 1 year \pm 4 months & 1.00 & $\mathrm{~B}$ & $4 \mathrm{~B}$ & -19.2 & 16.3 & 46.0 & 16.5 & 3.3 \\
\hline 50 & $1-2$ years & 1.50 & $\mathrm{~B}$ & $4 \mathrm{~B}$ & -19.8 & 15.1 & 46.2 & 17.2 & 3.1 \\
\hline 59 & $1-2$ years & 1.50 & $\mathrm{~B}$ & $4 \mathrm{~B}$ & -19.2 & 14.1 & 45.6 & 17.0 & 3.1 \\
\hline 146 & 1.3-1.9 years & 1.60 & $\mathrm{~B}$ & $4 \mathrm{~B}$ & -20.1 & 12.9 & 45.3 & 16.8 & 3.1 \\
\hline 392 & 1.8-1.9 years & 1.85 & $\mathrm{~B}$ & $4 \mathrm{~B}$ & -18.7 & 15.2 & 44.3 & 16.1 & 3.2 \\
\hline 260 & c. 2 years & 2.00 & $\mathrm{~B}$ & $4 B$ & -18.3 & 15.0 & 45.1 & 16.4 & 3.2 \\
\hline 225 & c. 2.5 years & 2.50 & $\mathrm{~B}$ & $4 \mathrm{~B}$ & -20.2 & 13.5 & 45.9 & 16.9 & 3.2 \\
\hline 84 & 3 years & 3.00 & $\mathrm{~B}$ & $4 \mathrm{~B}$ & -19.3 & 14.3 & 45.7 & 16.9 & 3.2 \\
\hline 255 & $3.1-3.2$ years & 3.15 & B & $4 \mathrm{~B}$ & -19.4 & 13.0 & 45.7 & 16.9 & 3.2 \\
\hline 407 & 4.5-5.5 years & 5.00 & $\mathrm{~B}$ & $4 \mathrm{~B}$ & -19.2 & 12.8 & 46.0 & 17.2 & 3.1 \\
\hline 6 & 4.9-5.2 years & 5.05 & $\mathrm{~B}$ & $4 \mathrm{~B}$ & -19.2 & 13.7 & 45.9 & 16.8 & 3.2 \\
\hline 52 & 5-6 years & 5.25 & $\mathrm{~B}$ & $4 \mathrm{~B}$ & -20.0 & 13.5 & 46.4 & 17.1 & 3.2 \\
\hline 419 & $5.1-5.5$ years & 5.30 & $\mathrm{~B}$ & $4 \mathrm{~B}$ & -18.8 & 12.9 & 45.2 & 16.8 & 3.1 \\
\hline 340 & 5.8-8.7 years & 6.25 & $\mathrm{~B}$ & $4 \mathrm{~B}$ & -20.6 & 12.2 & 46.1 & 17.0 & 3.2 \\
\hline 594 & $6.5-9.8$ years & 8.15 & $\mathrm{~B}$ & $4 \mathrm{~B}$ & -18.9 & 12.6 & 46.0 & 17.1 & 3.1 \\
\hline
\end{tabular}




\begin{tabular}{|c|c|c|c|c|c|c|c|c|c|}
\hline 380 & 7.9-9.8 years & 8.35 & $\mathrm{~B}$ & $4 \mathrm{~B}$ & -17.6 & 14.0 & 45.7 & 17.1 & 3.1 \\
\hline 145 & 7.5-9.5 years & 8.50 & $\mathrm{~B}$ & $4 \mathrm{~B}$ & -18.7 & 13.9 & 45.6 & 16.9 & 3.2 \\
\hline 201 & $10-12$ years & 11.00 & $\mathrm{~B}$ & $4 \mathrm{~B}$ & -19.3 & 13.2 & 45.7 & 16.8 & 3.2 \\
\hline 561 & $11-12$ years & 11.50 & $\mathrm{~B}$ & $4 \mathrm{~B}$ & -18.7 & 12.8 & 44.3 & 16.0 & 3.2 \\
\hline 322 & $12-14$ years & 13.00 & $\mathrm{~B}$ & $4 \mathrm{~B}$ & -20.3 & 12.1 & 45.9 & 17.0 & 3.1 \\
\hline Adult female (mean; $n=19$ ) & & & $B$ & & -19.2 & 13.5 & & & \\
\hline (1 stdev) & & & & & 0.4 & 0.5 & & & \\
\hline
\end{tabular}




\title{
Supplementary Material for Britton et al. 'Isotopes and new norms: investigating the emergence of early modern UK breastfeeding practices at St. Nicholas Kirk, Aberdeen'
}

\author{
Details of WARN package $R$ application, data description and presentation
}

\section{Methods}

The R package 'WARN' utilised to analyse data (Tsutaya and Yoneda 2013; R Core Team 2014) from St. Nicholas Kirk (Phases A and B), along with data from 5 other early medieval to early modern datasets from Britain. Data originated from 6 previous publications where full datasets were available (including individual values, data from sub-adults and adult females, and age data, etc.) or could be obtained using image capture software (Privat et al. 2002; Nitsch et al. 2010, 2011; Burt 2013; Haydock et al. 2013; Britton et al. 2015). The age of individuals used in this study was limited to below 10 years (after Tsutaya and Yoneda 2013), with ages being converted to midpoint values, and adult females from the same sites were used to calculate the female mean. Default parameters were used for the package (see details in Tsutaya and Yoneda 2013 inc. Supplementary Materials, and on-line notes at https://cran.r-project.org/web/packages/WARN/WARN.pdf). In brief, the prior distributions were set to have normal distributions with means of $0.5,3.0,1.9$, and $\delta^{15} \mathrm{~N}$ female mean and standard deviations (SDs) of 3.0, 3.0, 0.9, and 3.0 for t1, t2, E (enrichment) and $\delta^{15}$ Nwnfood (weaning food). The number of "particles" (i.e., unit sets of weaning parameters resampled) was 10000 . The number of parameter "populations" (i.e., units of successively reducing tolerance) was seven and the Credible Intervals (CI) threshold was set at 95\% (as per https://cran.r-project.org/web/packages/WARN/WARN.pdf).

\section{Results}

Model application results are summarised in Table S1. It should be noted that data from a number of other relevant case studies was not suitable for statistical analysis using the WARN package in $\mathrm{R}$ due to, for example, the analysis of intra-tooth dentinal collagen rather than bone (rib) collagen (e.g. Beaumont et al. 2013). Data from Raunds Furnells was extracted (reverse engineered) from scatter plots within the original publication (Haydock et al. 2013), using image capture and analysis software Phenocapture. For each of the case studies, results of applying the WARN model are presented in the figures below (Figures S2S8), and described in the caption of each composite image. 
S1 (Table S1): Summary of the results of the WARN model application to previously published datasets. Sites and data sources are: Berinsfield, Oxfordshire (Privat et al. 2002); Raunds Furnells, Northamptonshire (Haydock et al. 2013); Wharram Percy, Yorkshire (Britton et al. 2015);

Fishergate House, York (Burt 2013); Spitalfields, London (Nitsch et al. 2010, 2011) and St. Nicholas Kirk, Aberdeen (this study).

\begin{tabular}{|c|c|c|c|c|c|c|c|c|c|c|c|c|c|c|c|c|c|c|}
\hline \multirow[b]{2}{*}{ Site } & \multirow[b]{2}{*}{$\begin{array}{c}\text { Period } \\
\text { (century } \\
\text { AD) }\end{array}$} & \multirow[b]{2}{*}{$\begin{array}{c}n(<10 \\
\text { yrs })\end{array}$} & \multicolumn{4}{|c|}{$\begin{array}{l}\text { Maximum Density } \\
\text { Estimators (MDE) }\end{array}$} & \multicolumn{3}{|c|}{ Probability (MDEs) } & \multicolumn{7}{|c|}{ 95\% Credible Intervals (CI) } & \multicolumn{2}{|c|}{$\begin{array}{l}\text { Adult } \\
\text { females }\end{array}$} \\
\hline & & & $\mathbf{t 1}$ & $\mathbf{t} 2$ & $\mathbf{E}$ & $\begin{array}{c}\delta^{15} \mathbf{N} \\
\text { wnfood }\end{array}$ & $\begin{array}{l}p(t 1 \\
\& \text { t2) }\end{array}$ & $p \mathbf{E}$ & $\begin{array}{c}p \delta^{15} \mathrm{~N} \\
\text { wnfood }\end{array}$ & t1 & t2 & $\begin{array}{l}p(t 1 \\
\& \text { t2) }\end{array}$ & $\mathbf{E}$ & $p \mathbf{E}$ & $\begin{array}{c}\delta^{15} \mathrm{~N} \\
\text { wnfood }\end{array}$ & $\begin{array}{c}p \delta^{15} \mathrm{~N} \\
\text { wnfood }\end{array}$ & $\begin{array}{c}\text { Mean } \\
\delta^{15} N\end{array}$ & 1sd \\
\hline Berinsfield & $5^{\text {th }}-7^{\text {th }}$ & 15 & 0.3 & 5.2 & 1.7 & 9.6 & 0.002 & 0.177 & 0.169 & $0.0-3.7$ & $3.3-7.7$ & 0.951 & $1.4-2.2$ & 0.959 & $9.3-10.1$ & 0.964 & 9.6 & 0.7 \\
\hline $\begin{array}{l}\text { Raunds } \\
\text { Furnells } \\
\end{array}$ & $10^{\text {th }} / 11^{\text {th }}$ & 58 & 0.8 & 2.3 & 3.1 & 11.1 & 0.016 & 0.130 & 0.212 & $0.1-1.6$ & $1.7-2.7$ & 0.951 & $2.6-3.7$ & 0.951 & $108-11.4$ & 0.968 & 11.1 & 0.9 \\
\hline $\begin{array}{l}\text { St. Nicholas } \\
\text { Kirk (A) }\end{array}$ & $12^{\text {th }}-15^{\text {th }}$ & 34 & 1.8 & 2.3 & 2.5 & 12.4 & 0.027 & 0.158 & 0.188 & $0.8-2.2$ & $2-2.8$ & 0.953 & 2.0-3.0 & 0.970 & $12.0-12.8$ & 0.967 & 12.9 & 0.9 \\
\hline $\begin{array}{l}\text { Wharram } \\
\text { Percy }\end{array}$ & c. $12^{\text {th }}-14^{\text {th }}+$ & 43 & 0.5 & 1.7 & 2.9 & 8.1 & 0.027 & 0.139 & 0.173 & $0.0-1.3$ & 1.4-2.1 & 0.957 & 2.4-3.4 & 0.966 & 7.6-8.4 & 0.953 & 8.6 & 1.3 \\
\hline $\begin{array}{l}\text { Fishergate } \\
\text { House }\end{array}$ & $14^{\text {th }}-15^{\text {th }}$ & 50 & 0.3 & 1.5 & 4.2 & 12.3 & 0.043 & 0.147 & 0.223 & $0.0-1.0$ & $1.2-1.8$ & 0.954 & $3.8-4.8$ & 0.959 & $12.0-12.6$ & 0.952 & 11.3 & 1.0 \\
\hline $\begin{array}{l}\text { St. Nicholas } \\
\text { Kirk (B) }\end{array}$ & $15^{\text {th }}-18^{\text {th }}$ & 24 & 0.3 & 1.3 & 3.0 & 13.4 & 0.025 & 0.098 & 0.180 & $0.0-1.1$ & $0.8-1.8$ & 0.960 & $2.2-3.8$ & 0.962 & $13.0-13.8$ & 0.957 & 13.5 & 0.5 \\
\hline Spitalfields & $18^{\text {th }}-19^{\text {th }}$ & 61 & 0.5 & 1.6 & 2.0 & 12.7 & 0.021 & 0.171 & 0.227 & $0.0-1.2$ & $1.2-2.1$ & 0.961 & $1.6-2.5$ & 0.967 & $12.4-13.0$ & 0.958 & 13.3 & 0.6 \\
\hline
\end{tabular}


S2 (Figure S2, A-D): Berinsfield, Oxfordshire (5th-7th century; Privat et al. 2002)
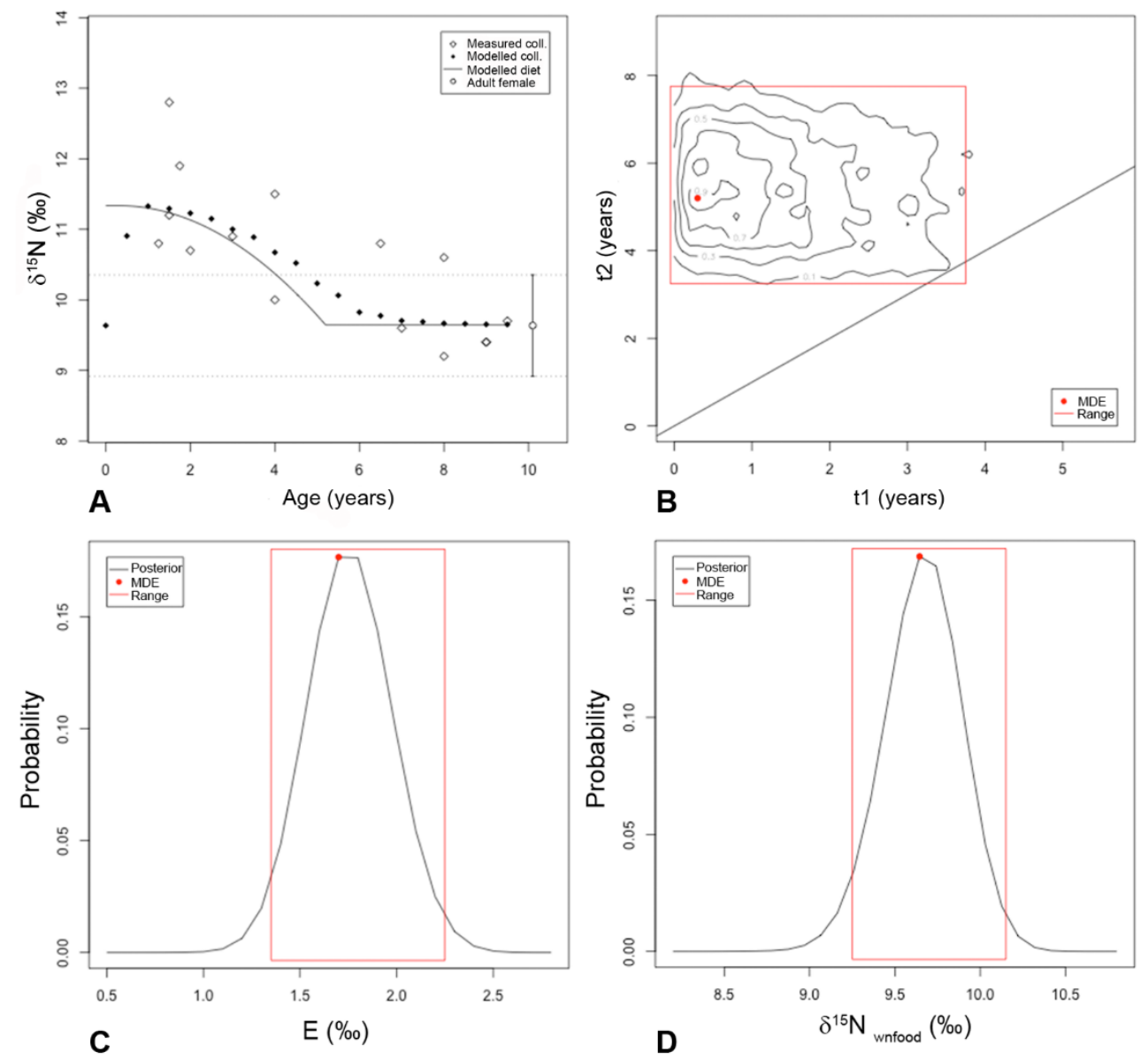

A. Modelled temporal changes in the $\delta^{15} \mathrm{~N}$ values of bone collagen and diet by sub-adult age at Berinsfield calculated from the reconstructed MDEs (Maximum Density Estimates). Adult female mean $( \pm 1$ s.d.) is indicated with open circles.

B. Contour lines show the posterior probability for the combination of weaning ages at Berinsfield. The target ranges for $\mathrm{t} 1$ and $\mathrm{t} 2$ are 0.0-3.7 yrs (MDE=0.3 yrs) and 3.3-7.7 yrs (MDE=5.2 yrs) respectively, and the calculated joint probability for the ranges is 0.951 .

C. Distribution of posterior probabilities for the ${ }^{15} \mathrm{~N}$-enrichment from material to infant tissues at Berinsfield. The range is 1.4-2.2 \%o and the calculated marginal probability for the range is 0.959 .

D. Distribution of posterior probabilities for the $\delta^{15} \mathrm{~N}$ values for collagen synthesised from weaning foods at Berinsfield. The range is 9.3-10.1\%o (MDE=9.6\%) and the calculated marginal probability for the range is 0.964 .

Sub-adult ages and sub-adult and female adult bone collagen values for Berinsfield were obtained from Privat et al. (2002). 
S3 (Figure S3, A-D): Raunds Furnells, Northamptonshire (10th/11th century; Haydock et al. 2013)
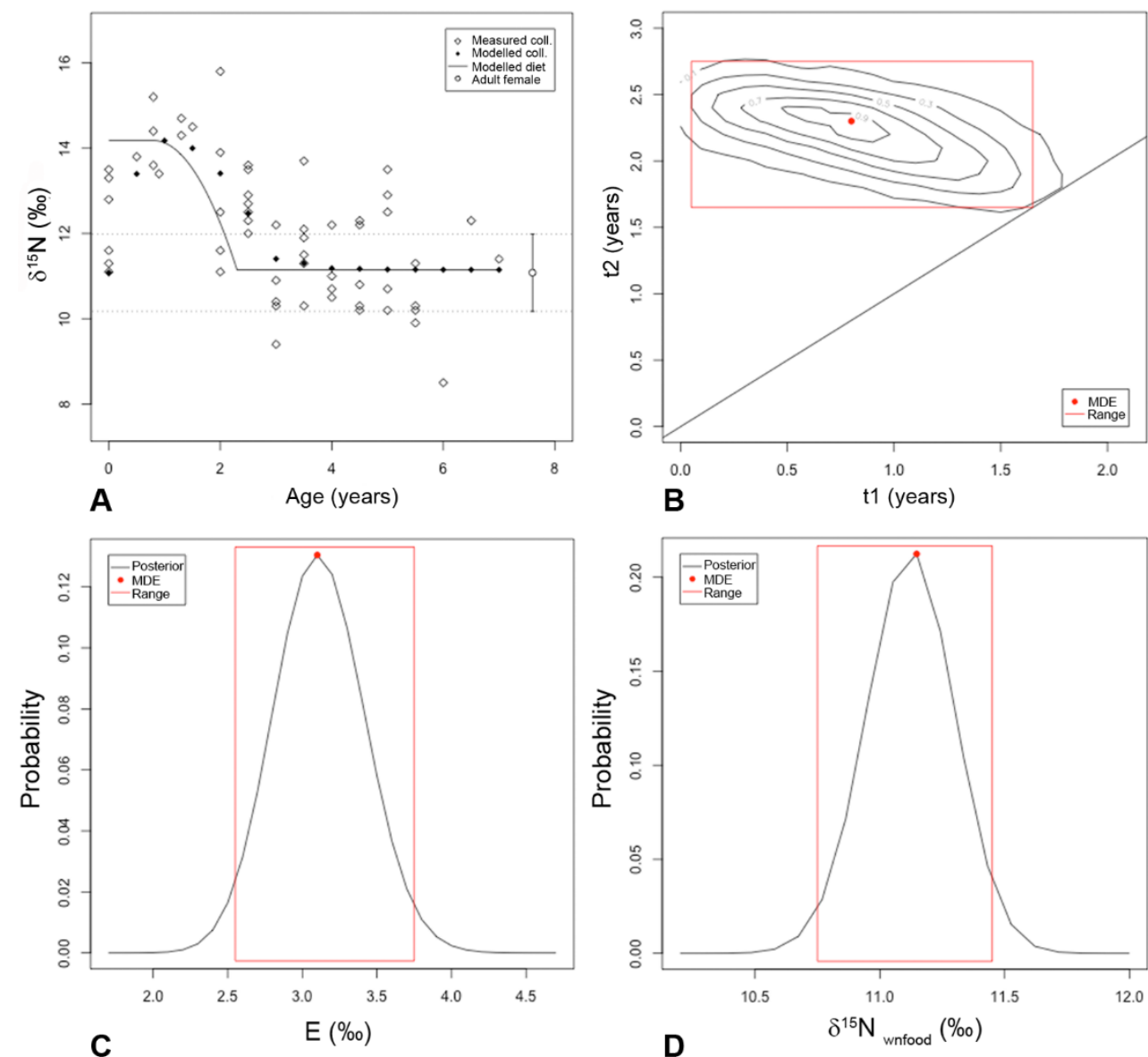

A. Modelled temporal changes in the $\delta^{15} \mathrm{~N}$ values of bone collagen and diet by sub-adult age at Raunds Furnells calculated from the reconstructed MDEs (Maximum Density Estimates). Adult female mean ( \pm 1 s.d.) is indicated with open circles.

B. Contour lines show the posterior probability for the combination of weaning ages at Raunds Furnells. The target ranges for $\mathrm{t} 1$ and $\mathrm{t} 2$ are 0.1-1.6 yrs (MDE=0.8 yrs) and 1.7-2.7 yrs (MDE=2.3 yrs) respectively, and the calculated joint probability for the ranges is 0.951 .

C. Distribution of posterior probabilities for the ${ }^{15} \mathrm{~N}$-enrichment from material to infant tissues at Raunds Furnells. The range is 2.6-3.7 \%o (MDE=3.1 \%o) and the calculated marginal probability for the range is 0.951 .

D. Distribution of posterior probabilities for the $\delta^{15} \mathrm{~N}$ values for collagen synthesised from weaning foods at Raunds Furnells. The range is 10.8-11.4\%o (MDE=11.1\%o) and the calculated marginal probability for the range is 0.968 .

Sub-adult ages and sub-adult and female adult bone collagen values were extracted (reverse engineered) from scatter plots in Haydock et al. (Haydock et al. 2013: 607-608, Figure 2 and Figure 3) using image capture and analysis software Phenocapture. 
S4 (Figure S4, A-D): St. Nicholas Kirk (Phase A; $12^{\text {th }}-15^{\text {th }}$ century), Aberdeen (this study)
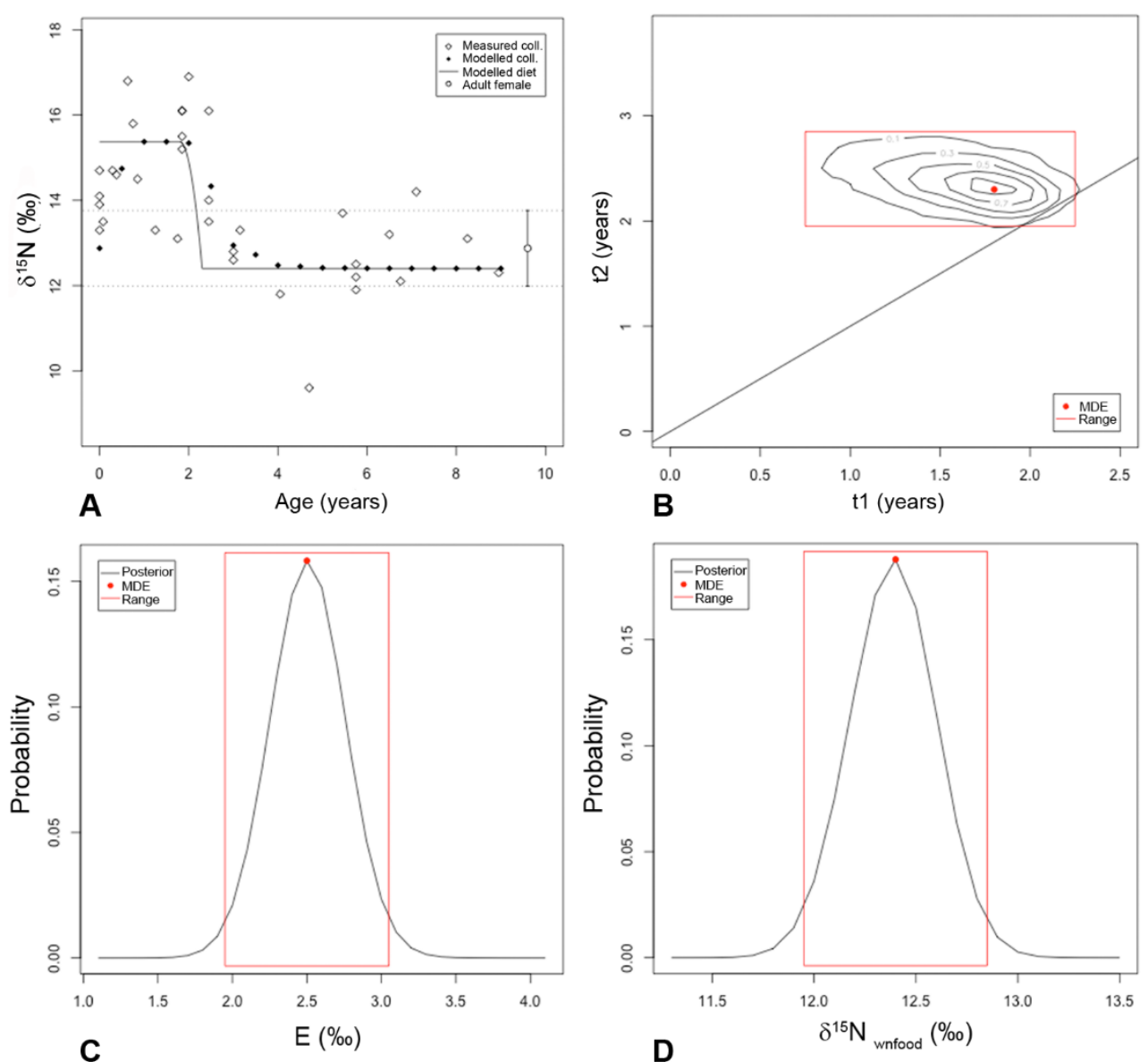

A. Modelled temporal changes in the $\delta^{15} \mathrm{~N}$ values of bone collagen and diet by sub-adult age at St. Nicholas Kirk (Phase A) calculated from the reconstructed MDEs (Maximum Density Estimates). Adult female mean ( \pm 1 s.d.) is indicated with open circles.

B. Contour lines show the posterior probability for the combination of weaning ages at St. Nicholas Kirk (Phase A). The target ranges for $\mathrm{t} 1$ and $\mathrm{t} 2$ are $0.8-2.2 \mathrm{yrs}$ (MDE=1.8 yrs) and 2-2.8 yrs (MDE=2.3 yrs) respectively, and the calculated joint probability for the ranges is 0.953 .

C. Distribution of posterior probabilities for the ${ }^{15} \mathrm{~N}$-enrichment from material to infant tissues at St. Nicholas Kirk (Phase A). The range is 2.0-3.0 \%o (MDE=2.5 \%o) and the calculated marginal probability for the range is 0.970 .

D. Distribution of posterior probabilities for the $\delta^{15} \mathrm{~N}$ values for collagen synthesised from weaning foods at St. Nicholas Kirk (Phase A). The range is 12.0-12.8 \%o (MDE=12.4 \%o) and the calculated marginal probability for the range is 0.967 .

Sub-adult ages and sub-adult and female adult bone collagen values for St. Nicholas Kirk (Phase A) are from this study (see Table 1 and Table 2, main document). 
S5 (Figure S5, A-D): Wharram Percy, Yorkshire ( 12-14th+ century; Britton et al. 2015)
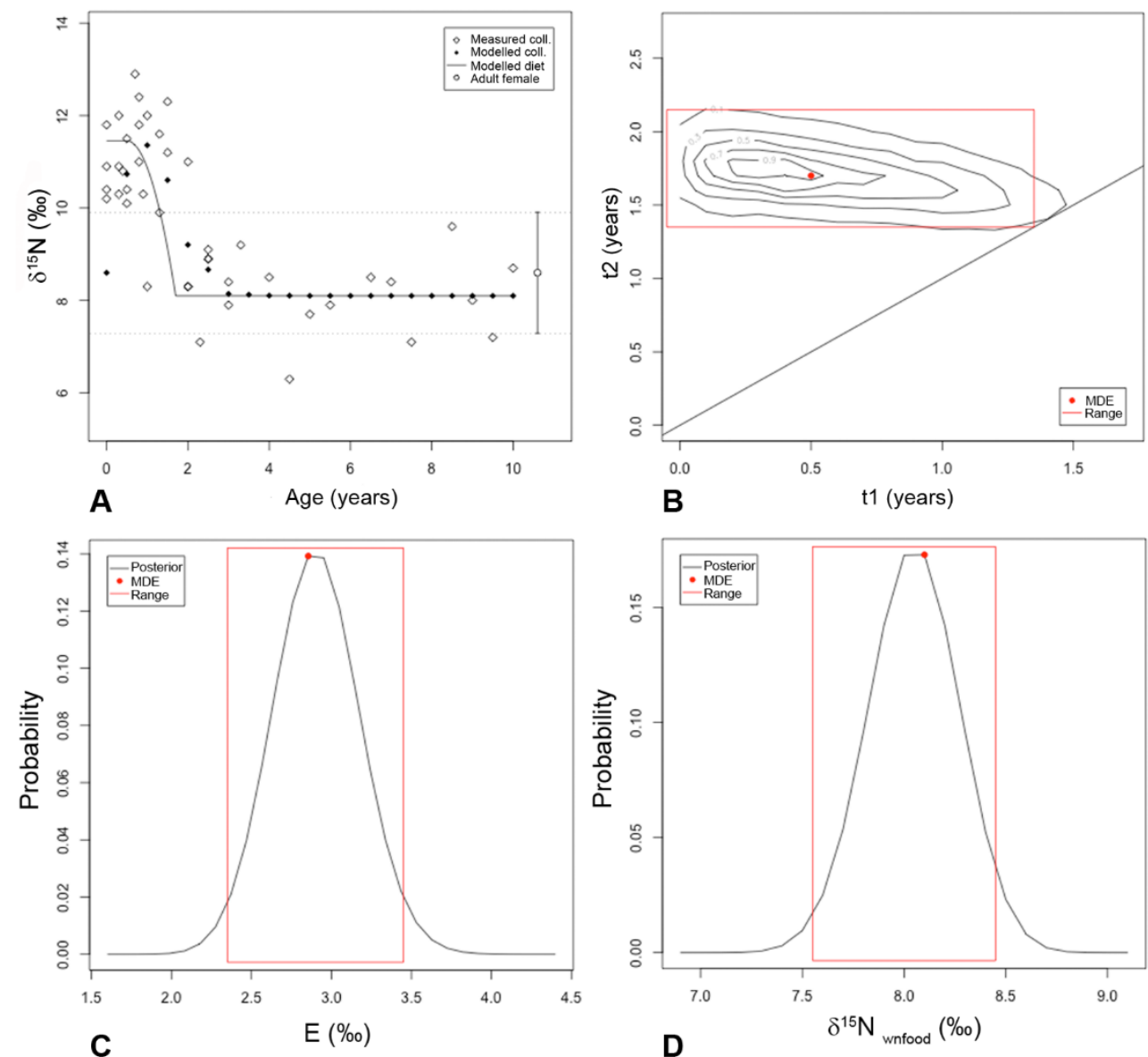

A. Modelled temporal changes in the $\delta^{15} \mathrm{~N}$ values of bone collagen and diet by sub-adult age at Wharram Percy calculated from the reconstructed MDEs (Maximum Density Estimates). Adult female mean ( \pm 1 s.d.) is indicated with open circles.

B. Contour lines show the posterior probability for the combination of weaning ages at Wharram Percy. The target ranges for $\mathrm{t} 1$ and $\mathrm{t} 2$ are 0.0-1.3 yrs (MDE $=0.5 \mathrm{yrs}$ ) and 1.4-2.1 yrs $(\mathrm{MDE}=1.7 \mathrm{yrs})$ respectively, and the calculated joint probability for the ranges is 0.957 .

C. Distribution of posterior probabilities for the ${ }^{15} \mathrm{~N}$-enrichment from material to infant tissues at Wharram Percy. The range is 2.4-3.4 \%o (MDE=2.9 \%o) and the calculated marginal probability for the range is 0.966 .

D. Distribution of posterior probabilities for the $\delta^{15} \mathrm{~N}$ values for collagen synthesised from weaning foods at Wharram Percy. The range is 7.6-8.4 \% (MDE=8.1\%o) and the calculated marginal probability for the range is 0.953 .

Sub-adult ages and sub-adult and female adult bone collagen values for Wharram Percy were obtained from Britton et al. (2015). 
S6 (Figure S6, A-D): Fishergate House, York (14th-15th century; Burt 2013)
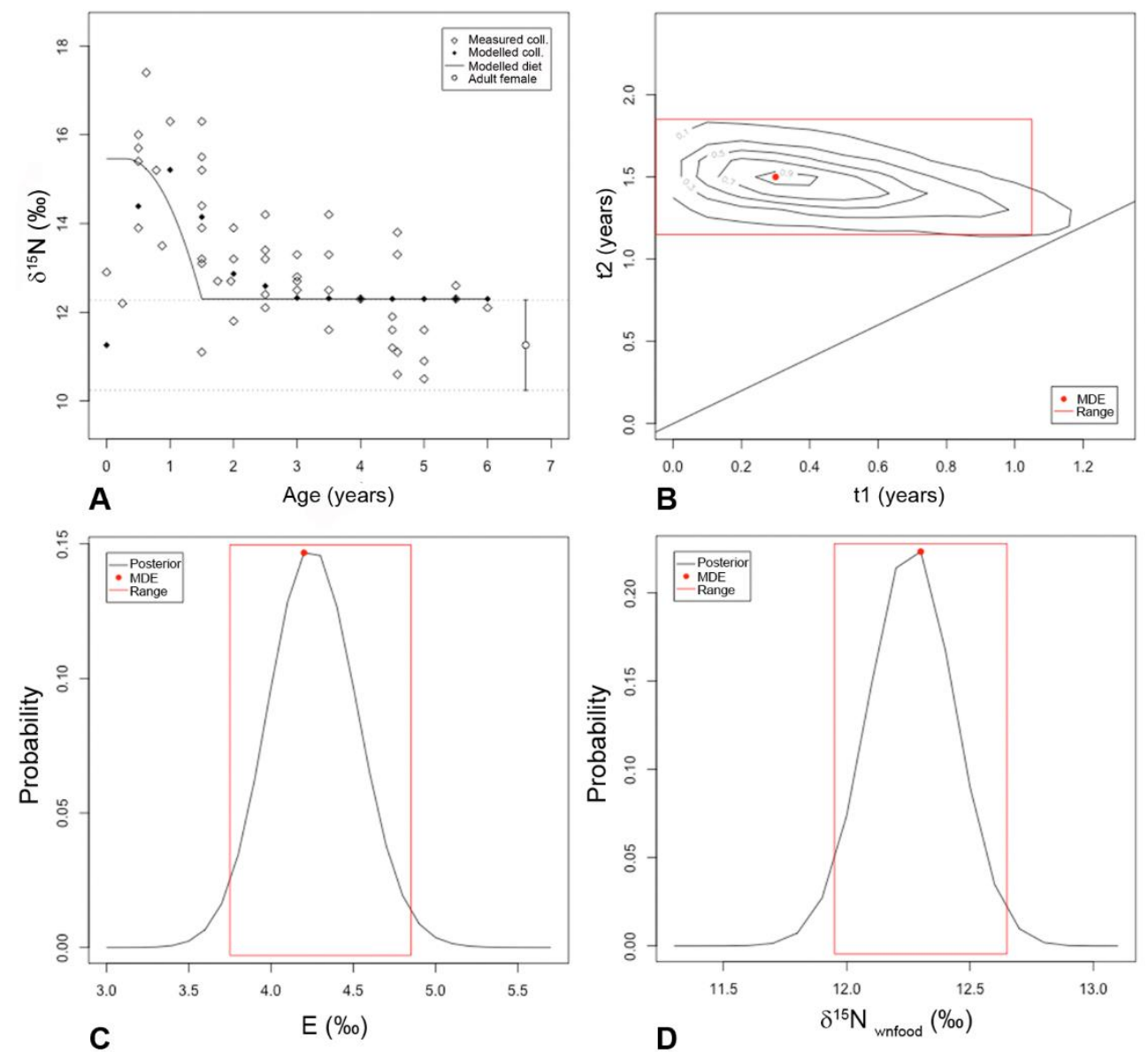

A. Modelled temporal changes in the $\delta^{15} \mathrm{~N}$ values of bone collagen and diet by sub-adult age at Fishergate House calculated from the reconstructed MDEs (Maximum Density Estimates). Adult female mean $( \pm 1$ s.d.) is indicated with open circles.

B. Contour lines show the posterior probability for the combination of weaning ages at Fishergate House. The target ranges for $\mathrm{t} 1$ and $\mathrm{t} 2$ are 0.0-1.0 yrs (MDE=0.3 yrs) and 1.2-1.8 $\mathrm{yrs}(\mathrm{MDE}=1.5 \mathrm{yrs})$ respectively, and the calculated joint probability for the ranges is 0.954 .

C. Distribution of posterior probabilities for the ${ }^{15} \mathrm{~N}$-enrichment from material to infant tissues at Fishergate House. The range is 3.8-4.8 \%o (MDE=4.2\%o) and the calculated marginal probability for the range is 0.959 .

D. Distribution of posterior probabilities for the $\delta^{15} \mathrm{~N}$ values for collagen synthesised from weaning foods at Fishergate House. The range is 12.0-12.6 \%o (MDE=12.3 \%o) and the calculated marginal probability for the range is 0.952 .

Sub-adult ages and sub-adult and female adult bone collagen values for Fishergate House were obtained from Burt (2013). 


\section{S7 (Figure S7, A-D): St. Nicholas Kirk (Phase B; $15^{\text {th }}-18^{\text {th }}$ century), Aberdeen (this study)}
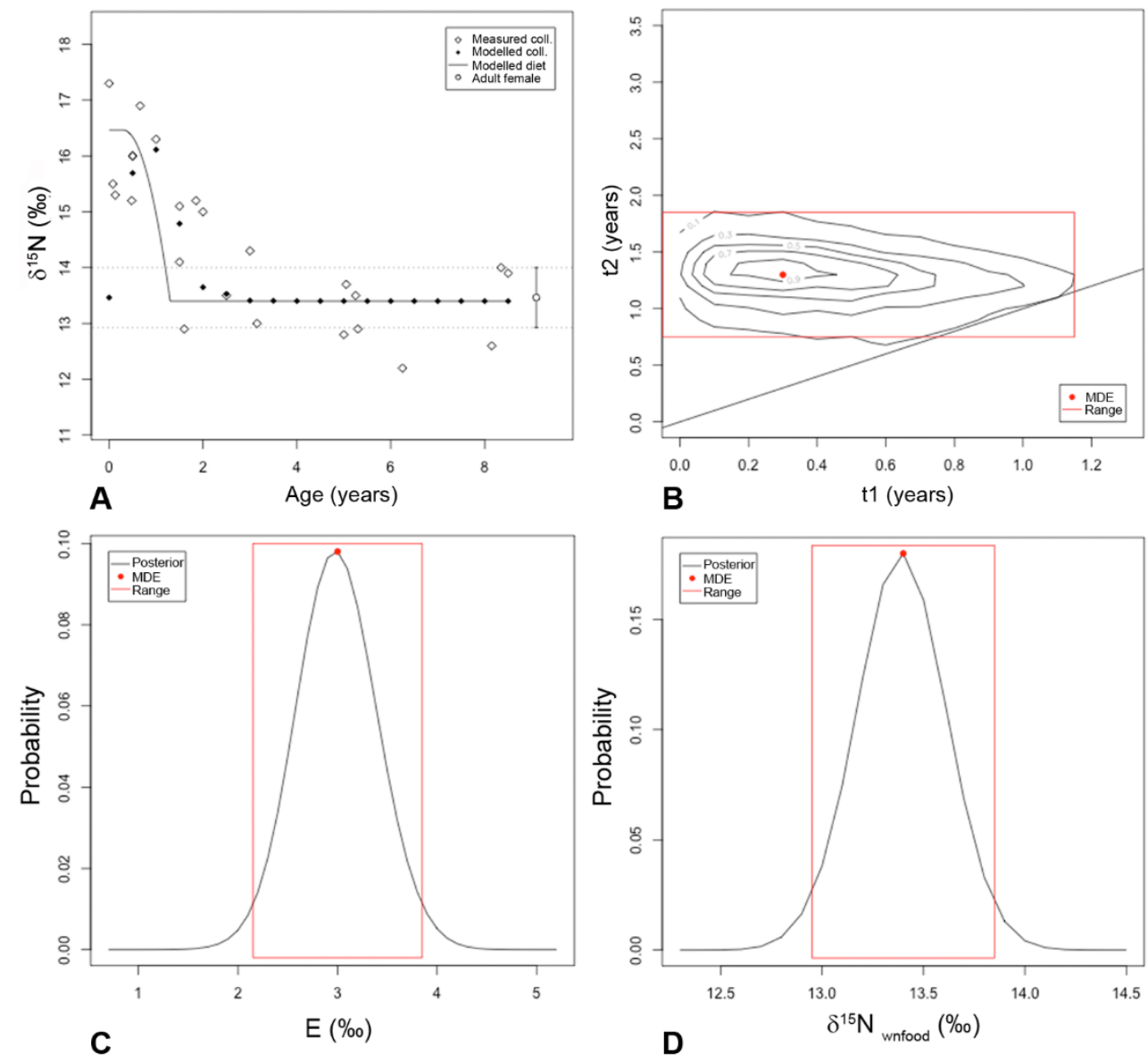

A. Modelled temporal changes in the $\delta^{15} \mathrm{~N}$ values of bone collagen and diet by sub-adult age at St. Nicholas Kirk (Phase B) calculated from the reconstructed MDEs (Maximum Density Estimates). Adult female mean ( \pm 1 s.d.) is indicated with open circles.

B. Contour lines show the posterior probability for the combination of weaning ages at St. Nicholas Kirk (Phase B). The target ranges for $\mathrm{t} 1$ and $\mathrm{t} 2$ are 0.0-1.1 yrs (MDE=0.3 yrs) and 0.8-1.8 yrs (MDE=1.3 yrs) respectively, and the calculated joint probability for the ranges is 0.960 .

C. Distribution of posterior probabilities for the ${ }^{15} \mathrm{~N}$-enrichment from material to infant tissues at St. Nicholas Kirk (Phase B). The range is 2.2-3.8 \%o (MDE=3.0 \%o) and the calculated marginal probability for the range is 0.962 .

D. Distribution of posterior probabilities for the $\delta^{15} \mathrm{~N}$ values for collagen synthesised from weaning foods at St. Nicholas Kirk (Phase B). The range is 13.0-13.8 \%o (MDE=13.4 \%o) and the calculated marginal probability for the range is 0.957 .

Sub-adult ages and sub-adult and female adult bone collagen values for St. Nicholas Kirk (Phase B) are from this study (see Table 1 and Table 2, main document). 
S8 (Figure S8, A-D): Spitalfields, London (18th-19th century; Nitsch et al. 2010; Nitsch et al. 2011)
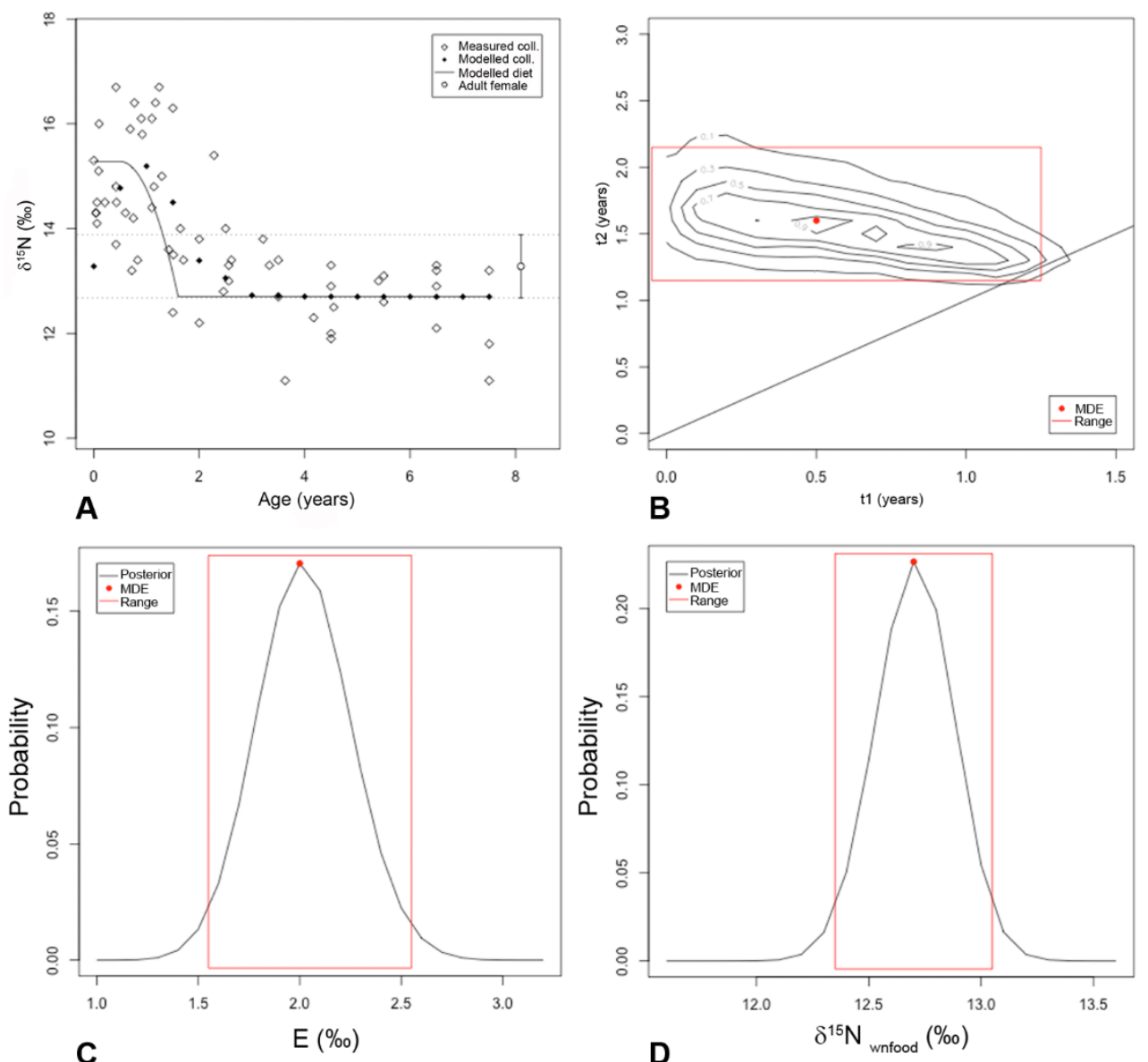

A. Modelled temporal changes in the $\delta^{15} \mathrm{~N}$ values of bone collagen and diet by sub-adult age at Spitalfields calculated from the reconstructed MDEs (Maximum Density Estimates). Adult female mean $( \pm 1$ s.d. $)$ is indicated with open circles.

B. Contour lines show the posterior probability for the combination of weaning ages at Spitalfields. The target ranges for $\mathrm{t} 1$ and $\mathrm{t} 2$ are 0.0-1.2 yrs (MDE=0.5 yrs) and 1.2-2.1 yrs $(\mathrm{MDE}=1.6 \mathrm{yrs}$ ) respectively, and the calculated joint probability for the ranges is 0.961 .

C. Distribution of posterior probabilities for the ${ }^{15} \mathrm{~N}$-enrichment from material to infant tissues at Spitalfields. The range is 1.6-2.5\% (MDE=2.0\%o) and the calculated marginal probability for the range is 0.967 .

D. Distribution of posterior probabilities for the $\delta^{15} \mathrm{~N}$ values for collagen synthesised from weaning foods at Spitalfields. The range is $12.4-13.0 \%$ o $(\mathrm{MDE}=12.7 \% 0)$ and the calculated marginal probability for the range is 0.958 .

Sub-adult ages and sub-adult and female adult bone collagen values at Spitalfields were obtained from Nitsch et al. $(2010,2011)$. It should be noted that the results of the WARN computation presented here for Spitalfields differ very slightly from those presented in Tsutaya and Yoneda (2013: Supplementary Material). These differences are due to the 
inclusion of additional samples from Nitsch et al. (2011) and (primarily) statistical uncertainty related to the 'trade-off' between computation time and the obtaining of a sufficient number of sampling data points inherent within the WARN programme itself. This means outputs of WARN from the same dataset can sometimes differ and are not equivalents (Takumi Tsutaya, personal communication). 


\section{References: Supplementary Material}

Beaumont, J., Gledhill, A., LeE-Thorp, J. \& Montgomery, J. 2013. Childhood diet: A closer examination of the evidence from dental tissues using stable isotope analysis of segmental human dentine. Archaeometry 55:277-295.

Britton, K., Fuller, B.T., TutKen, T., MAys, S. \& Richards, M.P. 2015. Oxygen isotope analysis of human bone phosphate evidences weaning age in archaeological populations. American Journal of Physical Anthropology 157:226-241.

BURT, N.M. 2013. Stable isotope ratio analysis of breastfeeding and weaning practices of children from medieval Fishergate House York, UK. American Journal of Physical Anthropology 152:407-416.

Haydock, H., Clarke, L., Craig-Atkins, E., Howcroft, R. \& Buckberry, J. 2013. Weaning at Anglo-Saxon Raunds: Implications for changing breastfeeding practice in Britain over two millennia. American Journal of Physical Anthropology 151:604-612.

NitsCH, E.K., HuMPHREY, L.T. \& HEDGES, R.E.M. 2011. Using stable isotope analysis to examine the effect of economic change on breastfeeding practices in Spitalfields, London, UK. American Journal of Physical Anthropology 146:619-628.

-2010 . The effect of parity status on $\delta 15 \mathrm{~N}$ : looking for the "pregnancy effect" in 18th and 19th century London. Journal of Archaeological Science 37:3191-3199.

PRIVAT, K.L., O'CONNELl, T.C. \& RICHARDS, M.P. 2002. Stable isotope analysis of human and faunal remains from the Anglo-Saxon cemetery at Berinsfield, Oxfordshire: Dietary and social implications. Journal of Archaeological Science 29:779-790.

R CORE TEAM 2014. R: A language and environment for statistical computing, R Foundation for Statistical Computing, Vienna, Austria., http://www.R-project.org/.

Tsutaya, T. \& YonedA, M. 2013. Quantitative Reconstruction of Weaning Ages in Archaeological Human Populations Using Bone Collagen Nitrogen Isotope Ratios and Approximate Bayesian Computation. PLoS ONE 8:e72327. 